\title{
Biogas upgrading, economy and utilization: a review
}

\author{
Shams Forruque Ahmed ${ }^{1}$ (D) M. Mofijur ${ }^{2,3} \cdot$ Karishma Tarannum $^{4,5} \cdot$ Anika Tasnim Chowdhury $^{1} \cdot$ Nazifa Rafa $^{5}$. \\ Samiha Nuzhat ${ }^{1,6} \cdot$ P. Senthil Kumar ${ }^{7} \cdot$ Dai-Viet N. Vo $^{8}$. Eric Lichtfouse ${ }^{9,10}$ - T. M. I. Mahlia ${ }^{2}$
}

\begin{abstract}
Biogas production is rising in the context of fossil fuel decline and the future circular economy, yet raw biogas requires puri-fication steps before use. Here, we review biogas upgrading using physical, chemical and biological methods such as water scrubbing, physical absorption, pressure swing adsorption, cryogenic separation, membrane separation, chemical scrubbing, chemoautotrophic methods, photosynthetic upgrading and desorption. We also discuss their techno-economic feasibility. We found that physical and chemical upgrading technologies are near-optimal, but still require high energy and resources. Biological methods are less explored despite their promising potential. High-pressure water scrubbing is more economic for small-sized plants, whereas potassium carbonate scrubbing provides the maximum net value for largesized plants.
\end{abstract}

Keywords Biogas utilization $\cdot$ Biogas upgrading technologies $\cdot$ Techno-economic analysis $\cdot$ Biogas purification $\cdot$ Biogas upgradation challenges $\cdot$ Biomethane

$\begin{array}{ll}\text { Abbreviations } \\ \text { BPFR } & \text { Biofilm plug flow reactor } \\ \mathrm{BCR} & \text { Bubble column reactor } \\ \mathrm{CaCO}_{3} & \text { Calcium carbonate } \\ \mathrm{CNG} & \text { Compressed natural gas } \\ \mathrm{Ca}(\mathrm{OH})_{2} & \text { Calcium hydroxide } \\ \mathrm{CO} & \text { Carbon monoxide } \\ \mathrm{CO}_{2} & \text { Carbon dioxide } \\ \mathrm{CH}_{4} & \text { Methane } \\ \text { FBR } & \text { Fixed bed reactor } \\ \text { GHG } & \text { Greenhouse gas } \\ \text { GRT } & \text { Gas retention time }\end{array}$

Shams Forruque Ahmed

shams.ahmed@auw.edu.bd; shams.f.ahmed@gmail.com

$\triangle$ P. Senthil Kumar

senthilkumarp@ssn.edu.in

1 Science and Math Program, Asian University for Women, Chattogram 4000, Bangladesh

2 Centre for Technology in Water and Wastewater, School of Civil and Environmental Engineering, Faculty of Engineering and Information Technology, University of Technology Sydney, Sydney, NSW 2007, Australia

3 Mechanical Engineering Department, Prince Mohammad Bin Fahd University, Al Khobar 31952, Saudi Arabia

4 Energy and Environment Unit, United Nations High Commissioner for Refugees (UNHCR), Dhaka, Bangladesh
$\mathrm{HCO}_{3} \quad$ Bicarbonate

HPWS High-pressure water scrubbing

$\mathrm{H}_{2} \mathrm{~S} \quad$ Hydrogen sulphide

$\mathrm{H}_{2} \mathrm{O} \quad$ Water

LBG Liquefied biogas

LBM Liquefied biomethane

LNG Liquid natural gas

$\mathrm{Mg}(\mathrm{OH})_{2} \quad$ Magnesium hydroxide

$\mathrm{NaOH}$ Sodium hydroxide

$\mathrm{N}_{2} \quad$ Nitrogen

$\mathrm{NH}_{3} \quad$ Ammonia

PSA Pressure swing adsorption
5 Environmental Sciences Program, Asian University for Women, Chattogram 4000, Bangladesh

6 Water and Life Bangladesh, Dhaka, Bangladesh

7 Department of Chemical Engineering, Sri Sivasubramaniya Nadar College of Engineering, Chennai 603110, India

8 Center of Excellence for Green Energy and Environmental Nanomaterials (CE@GrEEN), Nguyen Tat Thanh University, Ho Chi Minh City 755414, Vietnam

9 CNRS, IRD, INRAE, CEREGE, Aix-Marseille Univ, Avenue Louis Philibert, 13100 Aix en Provence, France

10 State Key Laboratory of Multiphase Flow in Power Engineering, Xi' an Jiaotong University, Xi'an 710049, Shaanxi, People's Republic of China 
TBR

UFR

Trickle-bed reactor

VOC Volatile organic compound

\section{Introduction}

Fossil fuels is currently the major energy source, with exploitation of fossil fuels meeting about $80 \%$ of global needs. Diminishing fossil fuel supplies and continuous greenhouse gas emissions are critical issues (Fairbrother et al. 2019; Ong et al. 2020). Carbon dioxide $\left(\mathrm{CO}_{2}\right)$ makes up the majority of greenhouse gas emissions (Ahmed et al. 2014; Silitonga et al. 2018; Zhang et al. 2020a). Increased atmospheric $\mathrm{CO}_{2}$ levels have been contributing to global warming and recurrent natural disasters (Abou Rjeily et al. 2021), which are likely to lead to population migration in various regions (Berlemann and Steinhardt 2017; Mofijur et al. 2016). As a result, interventions that remove atmospheric $\mathrm{CO}_{2}$ such as carbon capture and storage, and conversion are being increasingly investigated and developed (Mofijur et al. 2019; Osman et al. 2020; Raza et al. 2019). Nonetheless, mass-scale applications of such technologies are actually restricted by the lack of economic feasibility (Al-Mamoori et al. 2017; Raza et al. 2019; Vega et al. 2020). In addition, for sustainable development and economic growth, there must be a transition from carbon-based fossil fuels to neutral- and zero-carbon fuels using renewable energy sources. To meet global energy demands, renewables should occupy a larger share of energy supply by 2050 , even though the current rate of progress is significantly lagging due to economic implications (Murdock et al. 2020).

A realistic alternative to approaching the world's growing fossil fuel scarcity, energy demands (Ahmed et al. 2013), and climate change risks would be to opt for an initiative that is traditional, renewable, and economically competitive in comparison with fossil fuels, namely biofuels (Hazrat et al. 2021; Srivastava et al. 2020; Zamri et al. 2021). Biofuel production is experiencing considerable research, innovation, and development to meet the growing global energy demand (Muhammad et al. 2021; Peng et al. 2020; Rizwanul Fattah et al. 2020). Biofuels are expected to consistently supply nearly one-fourth of the primary energy in 2050 across the globe, where biogas is driving the emerging market for renewable energy (Nevzorova and Karakaya 2020). The biogas market should expand in the areas of cooking, power, heating, and transport (Lask et al. 2020).

Biogas can simultaneously address growing waste generation and management issues. Biogas upgrading technologies such as biological and hybrid methods, hydrate separation, biotechnologies (biotrickling filter, in situ upgrading), dry reforming, chemolithotroph-based bioreactors, and membrane technology are gaining attention, but are yet to be popularized on a large scale (Adnan et al. 2019). Different strategies have been encouraged to lower costs, such as the use of $\mathrm{CO}_{2}$ in enhanced oil recovery, algae production and mineralization, and underground carbon sequestration. Nonetheless, further attention should be placed on analysing the quality of separated $\mathrm{CO}_{2}$ for utilization because there is little information in this area. Topics of recent reviews on biogas upgrading technologies are compared in Table 1, showing that few reports address techno-economic analysis, biogas utilization, and challenges. Therefore, we review technologies available for upgrading biogas and their challenges. We explain how to choose technologies based on their final utilization and techno-economic feasibility.

\section{Biogas upgrading}

Biogas is produced by anaerobic digestion of waste generated from municipal, agricultural, and industry at moderateto-high temperature (Chew et al. 2021; Mofijur et al. 2021). The upgrading of biogas aims at separating methane from $\mathrm{CO}_{2}$ and other biogases. Biogas is mainly treated in two steps: first, raw biogas is cleaned through the removal of toxic compounds, then it is upgraded, or the $\mathrm{CO}_{2}$ content is adjusted to establish a high enough calorific value of the biogas (Bose et al. 2019). Although biogas primarily consists of $\mathrm{CO}_{2}$ and $\mathrm{CH}_{4}$, a number of compounds may also

Table 1 Topics of recent reviews on biogas upgrading technologies

\begin{tabular}{llllllll}
\hline Topics & $\begin{array}{l}\text { Struk et al. } \\
(2020)\end{array}$ & $\begin{array}{l}\text { Kapoor et al. } \\
(2019)\end{array}$ & $\begin{array}{l}\text { Angelidaki et al. } \\
(2018)\end{array}$ & $\begin{array}{l}\text { Sahota et al. } \\
(2018)\end{array}$ & $\begin{array}{l}\text { Ullah Khan } \\
\text { et al. (2017) }\end{array}$ & $\begin{array}{l}\text { Sun et al. } \\
(2015)\end{array}$ & This report \\
\hline Physical technologies & $\sqrt{ }$ & $\sqrt{ }$ & $\sqrt{ }$ & $\sqrt{ }$ & $\sqrt{ }$ & $\sqrt{ }$ & $\sqrt{ }$ \\
Chemical technologies & $\sqrt{ }$ & $\sqrt{ }$ & $\sqrt{ }$ & $\sqrt{ }$ & $\sqrt{ }$ & $\sqrt{ }$ & $\sqrt{ }$ \\
$\begin{array}{l}\text { Biological technologies } \\
\text { Techno-economic analysis }\end{array}$ & $\sqrt{ }$ & $\sqrt{ }$ & $\sqrt{ }$ & $\sqrt{ }$ & $\sqrt{ }$ & $\sqrt{ }$ & $\sqrt{ }$ \\
$\begin{array}{l}\text { Biogas utilization } \\
\text { Challenges }\end{array}$ & & & & $\sqrt{ }$ & $\sqrt{ }$ & & $\sqrt{ }$ \\
Perspectives & $\sqrt{ }$ & $\sqrt{ }$ & $\sqrt{ }$ & $\sqrt{ }$ & $\sqrt{ }$ & $\sqrt{ }$ & $\sqrt{ }$ \\
\hline
\end{tabular}


be present in biogas, namely water $\left(\mathrm{H}_{2} \mathrm{O}\right)$, dinitrogen $\left(\mathrm{N}_{2}\right)$, dioxygen $\left(\mathrm{O}_{2}\right)$, carbon monoxide $(\mathrm{CO})$, ammonia $\left(\mathrm{NH}_{3}\right)$, hydrogen sulphide $\left(\mathrm{H}_{2} \mathrm{~S}\right)$, volatile organic compounds (VOCs), siloxanes, aromatic and halogenated compounds, and hydrocarbons (Préat et al. 2020; Mahmudul et al. 2021). Upgrading can improve heating values to $15-30 \mathrm{MJ} / \mathrm{Nm}^{3}$ (Hosseini and Wahid 2014).

The composition of the biogas is controlled by the $\mathrm{pH}$ and the nature of raw materials utilized for digestion biogas (Chaemchuen et al. 2016). The combustibility of biogas is attributed to $\mathrm{CH}_{4}$, which determines the calorific value. Other biogas components are often viewed as contaminants. For example, $\mathrm{CO}_{2}$ significantly lowers the calorific value of the biogas, which can be used only for low-quality energy needs such as cooking and lighting (Awasthi et al. 2020). Moreover, large concentrations of $\mathrm{O}_{2}$ in the biogas may lead to explosions (Stolecka and Rusin 2021). Biogas is mainly criticized for its limited ability to reduce carbon emissions compared to other renewable sources (Raugei et al. 2020), yet a fully optimized process where all by-products are recycled into value-added compounds would be sustainable. In particular, more research is needed in cleaning technologies, process optimization, development of efficient adsorbents for biogas upgrade, improvement of storage systems, reduction of $\mathrm{CH}_{4}$ loss, minimization of environmental consequences, maintenance cost and energy usage, and efficient utilization pathways for biogas (Adnan et al. 2019; Awe et al. 2017; Chaemchuen et al. 2016; Khan et al. 2017).

\section{Available technologies for biogas upgrading}

The technologies for biogas upgrading are mainly derived from the gas refining industry. These technologies use separation and sorption approaches to take advantage of the chemical, physical, and biological properties of gas components.

\section{Physical technologies}

\section{Water scrubbing}

The water scrubbing principle utilizes the advantage of different solubility levels of the various components of biogas in a liquid scrubbing solution to separate and extract pure $\mathrm{CH}_{4}$ as biogas (Fig. 1). Depending on their solubility, different gas components physically bind with a scrubbing solvent. Water scrubbing involves the use of water as a selective solvent. This technology is widely used for industrial-scale upgrading (Wylock and Budzianowski 2017) and for a diverse array of flow rates of biogas, the most suitable

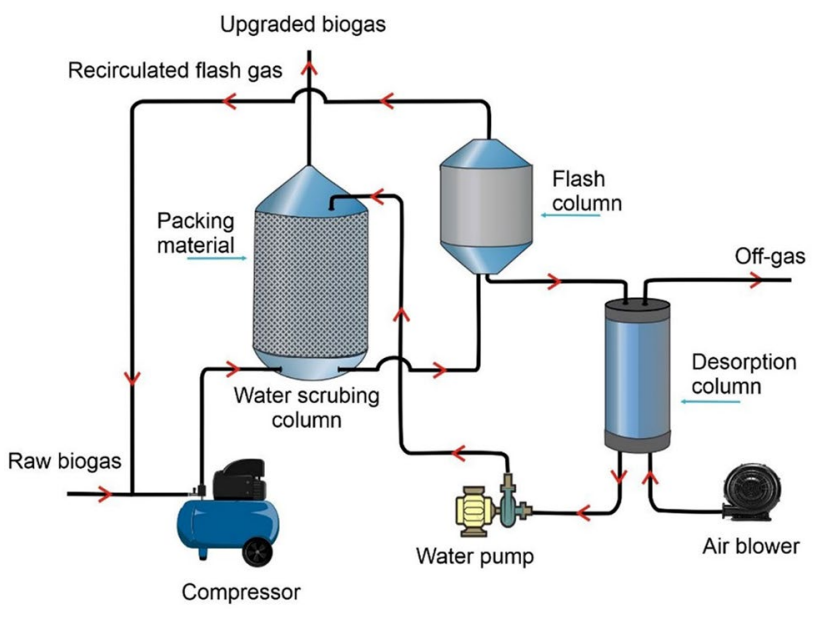

Fig. 1 Typical water scrubbing technology used for industrial-scale biogas upgradation. Here, water separates enriched methane from raw biogas

category being higher flow rates ranging from 500 to 2000 $\mathrm{Nm}^{3} / \mathrm{h}$ (Petersson and Wellinger 2009).

Hydrogen sulphide $\left(\mathrm{H}_{2} \mathrm{~S}\right)$ has the highest solubility in water among biogas components followed by $\mathrm{CO}_{2}$. However, $\mathrm{H}_{2} \mathrm{~S}$ in gaseous form is harmful and toxic to the environment. When $\mathrm{H}_{2} \mathrm{~S}$ is mixed with water, it becomes corrosive and odorous; therefore, $\mathrm{H}_{2} \mathrm{~S}$ is usually pre-separated from biogas prior to water scrubbing when it reaches an amount higher than 300 to 2500 ppmv (Thrän et al. 2014). Following that, $\mathrm{CO}_{2}$, which is 26 times more soluble than $\mathrm{CH}_{4}$ in water at a temperature of $25^{\circ} \mathrm{C}$, is dissolved in the water (Towler and Sinnott 2012). The absorption of $\mathrm{CO}_{2}$ happens at 8-10 bar, yet pressures ranging from 10 to 20 bar are varyingly used at the absorption column (Kapoor et al. 2017). As $\mathrm{CH}_{4}$ has the lowest solubility among the other components in biogas, this method is extensively used for cleaning biogas with water as a scrubbing agent. With this technology, 80-99\% $\mathrm{CH}_{4}$ purity can be achieved; however, it relies on the concentrations of non-condensable impurities that are inseparable from $\mathrm{CH}_{4}$, such as $\mathrm{N}_{2}$ and $\mathrm{O}_{2}$ (Sun et al. 2015).

In order to facilitate gas-to-liquid mass transfer, an absorption column is used where compressed biogas is injected upwards from the base and water downwards from the top in a counter-current flow (Hosseinipour and Mehrpooya 2019). Water saturated biomethane is collected from the upper end of the column, whereas the $\mathrm{CO}_{2}$ and $\mathrm{H}_{2} \mathrm{~S}$ filled water is decompressed in a desorption column to remove the $\mathrm{CO}_{2}$ and $\mathrm{H}_{2} \mathrm{~S}$ and regenerate pure water for reuse in scrubbing. In the desorption column, pressure decreases to 2.5-3.5 bar, and residual $\mathrm{CH}_{4}$ dissolved in the water is recovered (Benizri et al. 2019). This regeneration of water is crucial due to this technology's demand for large quantities of water. Although water recirculation is cost-effective, if the water source is a wastewater treatment plant, a single 
pass of water is recommended. However, to reduce the cost of the single-pass process, the $\mathrm{CO}_{2}$ is not separated from the water, rather, the water/ $\mathrm{CO}_{2} \mathrm{mix}$ is released into the treatment facility after scrubbing for further treatment.

$\mathrm{CO}_{2}$ is released into the atmosphere only in the case of recirculation and water reused in the system. Even then, if the biogas flow rates are in the range of $100-1000 \mathrm{Nm}^{3} / \mathrm{h}$ or $20-200 \mathrm{~L} / \mathrm{h}$, it is necessary to supply fresh water into the water circulation system to avoid an accumulation of toxicants such as elemental sulphur (Kapoor et al. 2019). Typically, the $\mathrm{CO}_{2}$ released in the process of water regeneration is not captured. Nevertheless, this loss can be addressed by introducing air stripping into the system which can potentially ensure that the purity of the $\mathrm{CO}_{2}$ is as high as $80-90 \%$. Using this method, the produced $\mathrm{CH}_{4}$ is saturated with water, hence drying is required to finalize the upgrading.

Apart from the cost of raw gas compression and water processing via circulation pumps, the air stripping step creates an additional electricity cost to run the air fan required for biomethane drying. The loss of $\mathrm{CH}_{4}$ in this technology stands between 3 and 5\% as per mathematical calculations; however, the claim equipment suppliers occasionally make is that this figure can be controlled and kept under $2 \%$ (Sun et al. 2015). On the other hand, the highest percentage loss of $\mathrm{CH}_{4}$ so far recorded is $18 \%$. Despite all this, this technology is very environmentally friendly and provides efficient biomethane upgrading without using any hazardous chemicals. Overall, water scrubbing technology is found to be efficient in removing impurities from biogas $\left(\sim 97 \% \mathrm{CH}_{4}\right.$ recovery), and both $\mathrm{CO}_{2}$ and $\mathrm{H}_{2} \mathrm{~S}$ can be removed at once. However, higher investment and operating costs are needed for this technology.

\section{Physical absorption of organic solvent scrubbing}

The fundamentals of the organic solvent scrubbing technology (Fig. 2) are identical to water scrubbing, the only difference being that dimethyl ethers of polyethylene glycol-based absorbents such as Selexol ${ }^{\circledR}$ or Genosorb $\AA$ are used as the scrubbing solvent instead of water. This is because these organic solvents usually have a higher binding capacity for $\mathrm{CO}_{2}$ and $\mathrm{H}_{2} \mathrm{~S}$ than water (Zhang et al. 2020b). Better affinity means less solvent is needed to run the process. In addition, organic absorbents like polyethylene glycol dimethyl ethers have low vapour pressure which leads to a minimal loss of solvent, resulting in a lower overall requirement for the solvent in this process (Nguyen et al. 2020). The advantage of using an organic solvent instead of water is that a small volume of solvent does the job efficiently, thereby lowering the amount of the solvent and allowing the size of the facility to be kept more compact (Yu et al. 2020).

Organic scrubbing is used mainly for the higher flow rates of 500-2000 Nm $3 /$ h (Ryckebosch et al. 2011). At the beginning of the process, both biogas and absorbent are cooled down to $20{ }^{\circ} \mathrm{C}$ and compressed by applying 7-8 bar pressure (Angelidaki et al. 2018). In addition to the fundamental steps of water scrubbing, organic solvent scrubbing technology requires a step to separate water from gas and subsequent steps that heat up to $40^{\circ} \mathrm{C}$ to promote desorption of $\mathrm{CO}_{2}$. Alongside $\mathrm{CO}_{2}$, moisture content, $\mathrm{O}_{2}, \mathrm{~N}_{2}$, and some trace amounts of halogenated hydrocarbons are also removed (Andriani et al. 2020). An additional benefit of this technology is that organic absorbents are by nature usually anti-corrosive; thus, expensive construction using stainlesssteel or extra coating materials is not required resulting in reduced investment and operational costs. Further, drying the biomethane is not necessary because glycol effectively
Fig. 2 Typical organic scrubbing process using dimethyl ethers of polyethylene glycolbased absorbents as the scrubbing solvent. Organic scrubbing is efficient in removing carbon dioxide, moisture content, oxygen, nitrogen, and trace amounts of halogenated hydrocarbons

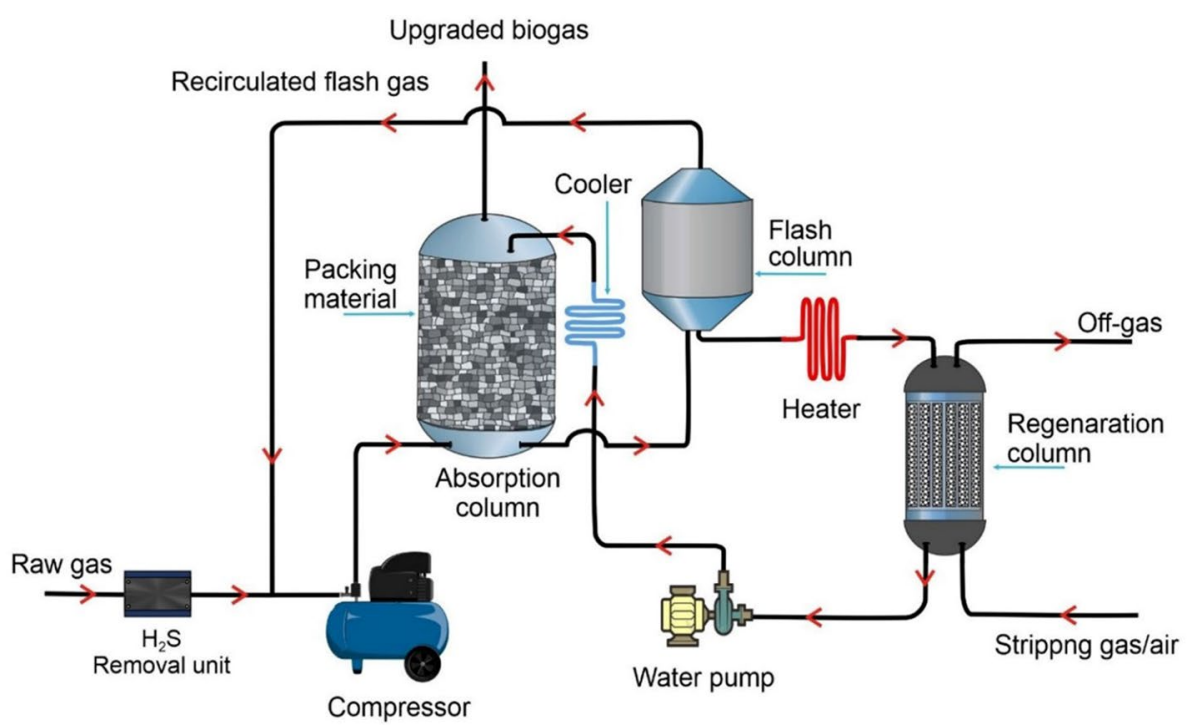


absorbs both water and halogenated hydrocarbon from the raw biogas (Qyyum et al. 2020).

Despite its multiple advantages, the well-developed organic solvent scrubbing technology only represents a $6 \%$ share of the international upgrading market (Zhao et al. 2017). Using this technology, a $96-98.5 \% \mathrm{CH}_{4}$ recovery rate can be achieved, and the loss of $\mathrm{CH}_{4}$ can be kept below $2 \%$ with high efficiency (Awe et al. 2017). Like water scrubbing, for higher concentrations of $\mathrm{H}_{2} \mathrm{~S}$, pre-separation is recommended using an activated carbon filter to minimize energy costs. If the concentration is relatively low, $\mathrm{H}_{2} \mathrm{~S}$ is allowed in the scrubbing process. However, as the solubility of biogas components is excessively high in organic solvents, regeneration is challenging and requires further processing for this technology. Because $\mathrm{H}_{2} \mathrm{~S}$ has even more solubility than $\mathrm{CO}_{2}$ in an organic solvent, with an increasing volume of $\mathrm{H}_{2} \mathrm{~S}$ present in the raw biogas, proportionally more heating is necessary to regenerate the solvent. Steam or inert gas flow is normally applied to allow absorbent regeneration and the prevention of sulphur build-up-related fouling in the system (Agbroko et al. 2017). Although this technology is more advanced than water scrubbing, the energy demand is significantly higher for organic solvent regeneration, and the solvents are quite expensive compared to water. In brief, organic scrubbing technology offers more than $97 \% \mathrm{CH}_{4}$ recovery efficiency. Also, it requires less amount of solvent because of the high solubility of $\mathrm{CO}_{2}$, while more energy is needed for the regeneration of solvents.

\section{Pressure swing adsorption}

The core of the adsorption technique is mainly found in porous adsorbents. Adsorbents like zeolite, silica gel, activated carbon, activated alumina and polymeric materials offer a high precision selective surface which is useful for the preferential adsorption of $\mathrm{CO}_{2}$ over $\mathrm{CH}_{4}$ (HunterSellars et al. 2020). Except for flow rates above $2000 \mathrm{Nm}^{3} / \mathrm{h}$, pressure swing adsorption (PSA) (Fig. 3) can be used for a broad spectrum of biogas flow points. The adsorbent characteristic is the most crucial determinant of PSA efficiency. The separation process of this method relies on the principles of selective adsorption affinity for different molecular sizes. The adsorbents act as a molecular filter with an average mesh size of $3.7 \mathrm{~A}^{\circ}: \mathrm{CO}_{2}$ atoms with a molecular size of $3.4 \mathrm{~A}^{\circ}$ are adsorbed, whereas $\mathrm{CH}_{4}$ atoms with a bigger molecular size of $3.8 \mathrm{~A}^{\circ}$ are excluded from retention inside the absorbent (Nakao et al. 2019). As a result, the $\mathrm{CH}_{4}$ unable to enter the porous adsorbent is left behind in the biogas at an increased concentration.

Apart from exhibiting a linear adsorption isotherm, any suitable adsorbent should remain stable both mechanically and thermally upon long-term usage, be non-hazardous, and readily available (Canevesi et al. 2018). Typically, adsorbents are vertically stacked and sequentially interconnected in four columns as shown in Fig. 3. Different operational stages of the pressure swing adsorption technology are biogas feeding and adsorption followed by blowdown and purging, and finally, column pressurization (Vilardi et al. 2020). Adsorption columns function under 4-10 bar pressure at different stages for enhanced $\mathrm{CO}_{2}$ adsorption (Wahono et al. 2020). Upon saturation of any column with $\mathrm{CO}_{2}$, the gas flow goes to the next column which has been already regenerated-this step is known as the blowdown phase. The blowdown phase lowers the overall energy requirement and serves as the pressurization stage for the next adsorption column. Following this, the additional pressure is withdrawn from the saturated
Fig. 3 Pressure swing adsorption system, which can be used for a broad spectrum of raw biogas. The separation relies on selective adsorption affinity for different molecular sizes

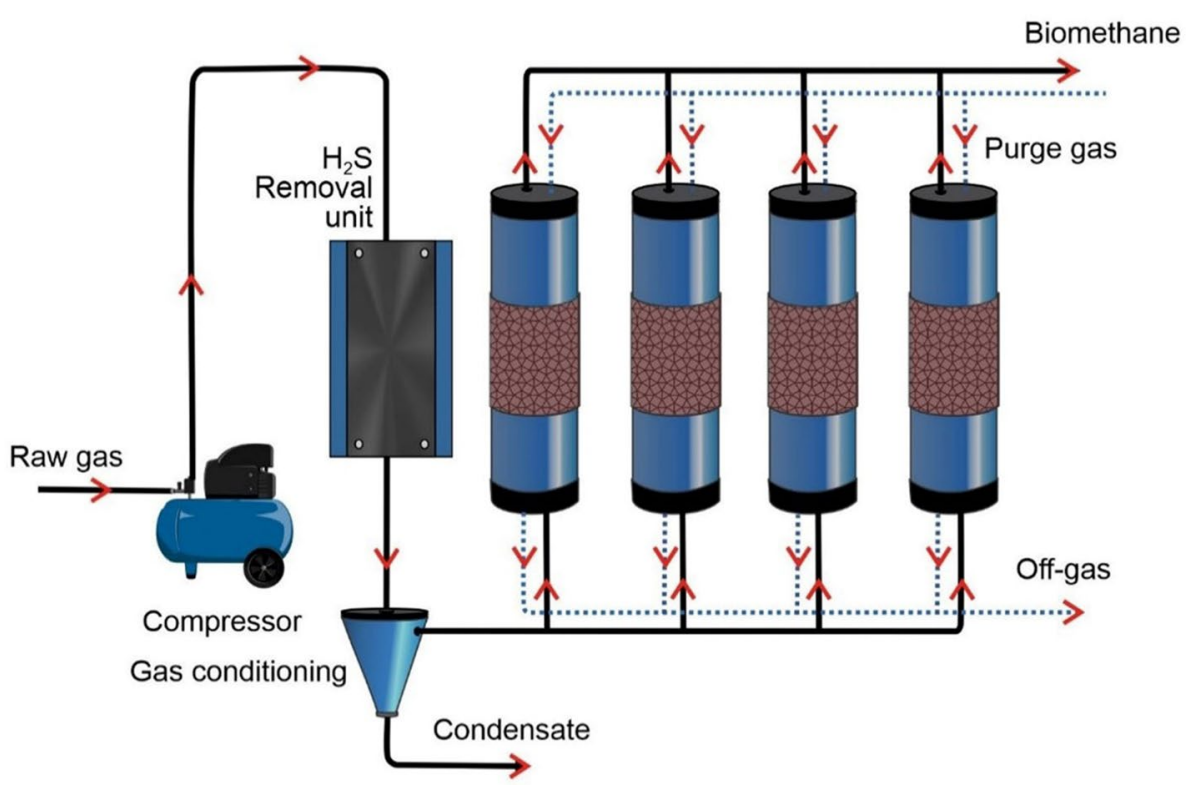


column which causes purging of the upgraded biogas and completes the regeneration of the adsorbent bed.

The regeneration capacity and efficiency of the upgrading of any adsorbent material varies under different temperature and pressure conditions. Unaffected by the adsorption process, $\mathrm{CH}_{4}$ remains in the flow and is periodically extracted from the tip of the columns under decreased pressure conditions. One of the columns performs adsorption at any given time, while the rest are engaged in different stages of regeneration. This recurring order of adsorption and regeneration takes just 2 to 10 min to complete (Qasem and Ben-Mansour 2018). Originally developed for industrial use during 1960s, the well-developed pressure swing adsorption technology has by now gained a $21 \%$ global market share (Patterson et al. 2011). A 96-98\% $\mathrm{CH}_{4}$ purity on top of a 94-96\% technical plant can be attained with this technology (Paolini et al. 2019). The moisture content of the raw biogas needs to be eliminated by condensation before adsorption (Bauer et al. 2013a).

Studies (Zhang et al. 2021, 2020c) suggest that $\mathrm{H}_{2} \mathrm{~S}$ and siloxanes should be filtered out with activated carbon filters prior to adsorption as they can corrupt the system by being irreversibly adsorbed onto the molecular sieves. Generally, $0.24-0.6 \mathrm{kWh} / \mathrm{Nm}^{3}$ electricity is applied for gas compression and condensation of moisture (Awe et al. 2017). The standard condition for adsorption involves the application of 3-8 bar pressure and high temperature ranging from 50 to $60{ }^{\circ} \mathrm{C}$. There are no other supplementary expenses for water supply or heating for adsorbent regeneration. However, the vent gas from the system with a high concentration of $\mathrm{CH}_{4}$ must be treated diligently before being released into the atmosphere (Nisbet et al. 2020), e.g. it can be treated by burning using a flox burner. At a glance, pressure swing adsorption involves faster installation and relatively easier operation due to compact setup. It is suitable for purifying small capacities of biogas. However, prior elimination of $\mathrm{H}_{2} \mathrm{~S}$ and moisture is preferable in this technology.

\section{Cryogenic separation}

Raw biogas components have different liquefaction and solidification temperatures, and cryogenic separation technology has been developed utilizing this factor. Cryogenic technology is popular for isolating impurities from raw biogas originating from landfills (Kapoor et al. 2019). In the cryogenic separation process, as shown in Fig. 4, the temperature of the raw biogas is decreased in a step-by-step manner, which helps in sequential and selective separation of moisture, $\mathrm{CO}_{2}, \mathrm{~N}_{2}, \mathrm{O}_{2}, \mathrm{H}_{2} \mathrm{~S}$, and $\mathrm{CH}_{4}$ from the raw gas flow. This sequential separation is also capable of generating pure liquefied biomethane (LBM) at a temperature of around $162{ }^{\circ} \mathrm{C}$ to $182{ }^{\circ} \mathrm{C}$ (Bauer et al. 2013b). The cryogenic separation technology has a promising potential for producing liquefied biomethane, and liquefied biomethane has an ignition efficiency equivalent to liquid natural gas (LNG) (Awe et al. 2017). It is a good choice for optimization since the cryogenic techniques produce products with a high purity ranging from 95 to $99 \%$ (Baena-Moreno et al. 2019b). The process takes place at a constant pressure of 10 bar using a series of successive temperature reductions.

At the first step of the cryogenic separation technology, the temperature reduction to $-25^{\circ} \mathrm{C}$ captures moisture, $\mathrm{H}_{2} \mathrm{~S}$, and trace amounts of siloxanes and halogens. Following this, in the second step the temperature drops to $-55^{\circ} \mathrm{C}$, and most of the $\mathrm{CO}_{2}$ is liquefied and removed from the process for further commercial upgrading. At the final polishing

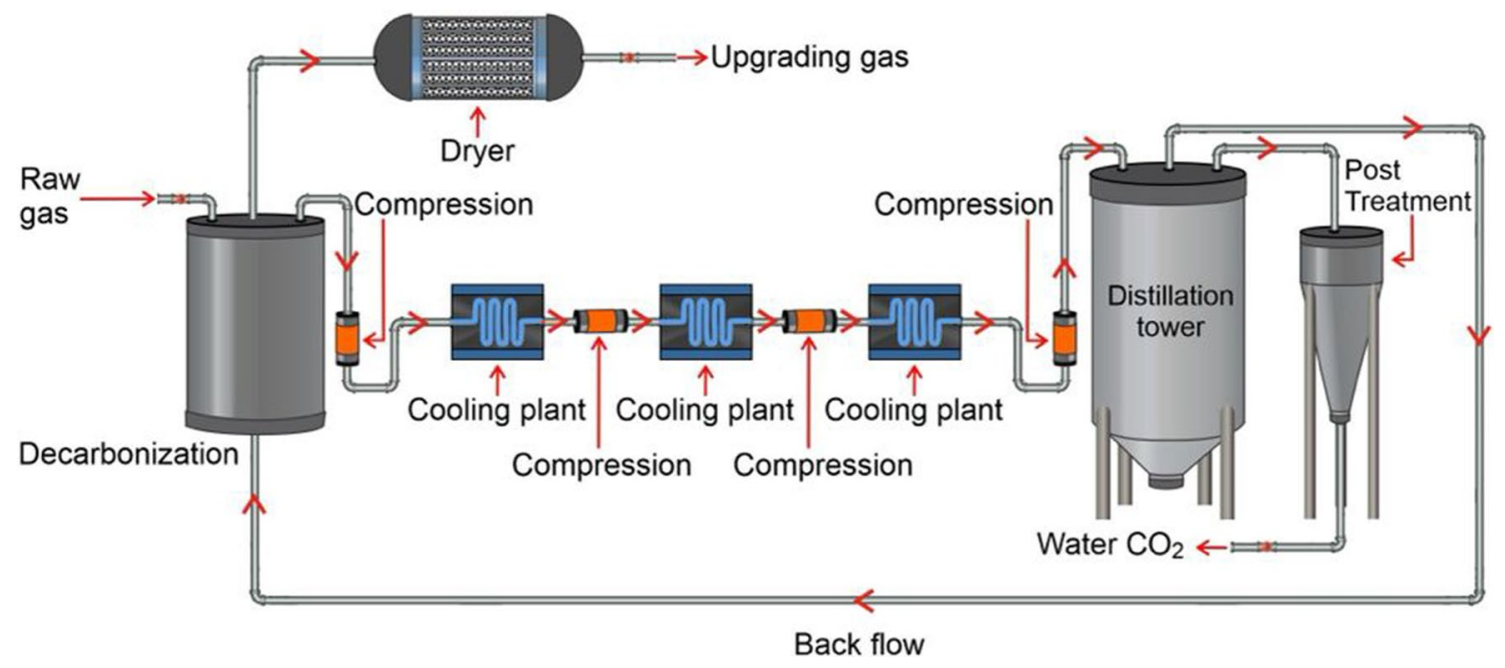

Fig. 4 Cryogenic separation of raw biogas. This process contains an initial biogas de-moisturizing step followed by a series of multiple compression and intermittent cooling stages 
step, residual $\mathrm{CO}_{2}$ condenses when the temperature reaches as low as $-80^{\circ} \mathrm{C}$ (Ryckebosch et al. 2011). It is necessary to keep applying high pressure throughout the process in order to avoid sudden solidification of $\mathrm{CO}_{2}$ under $-78{ }^{\circ} \mathrm{C}$, which can result in operational complications such as congestion of pipelines and undesirable fluctuations in temperature. Preremoval of water and $\mathrm{H}_{2} \mathrm{~S}$ can also prove beneficial in this regard. A setup of horizontally interconnected compressors and heat exchangers is required to meet these operating conditions (Yousef et al. 2016). Additionally, turbines and distillation columns are essential for the full functioning of the system, further increasing the overall cost of the cryogenic separation technology (Kiss and Smith 2020). Such extensive process equipment setup results in huge investment and operational costs.

The operational procedure of the cryogenic separation technology usually contains an initial biogas de-moisturizing step followed by a series of multiple compression and intermittent cooling stages ranging up to 80 bar pressure. Prior to that, raw gas is compressed using up to 200 bar pressure. The huge energy required to reach this high-pressure level that is equivalent to $5-10 \%$ of the biomethane produced (Allegue et al. 2012; Hashemi et al. 2019). Despite the capability of biomethane liquefaction, cryogenic separation has not yet captured the attention of the global market for full-scale commercialization and represents only $0.4 \%$ of the market. A $97 \%$ biomethane purity and lower than $2 \%$ $\mathrm{CH}_{4}$ loss can be achieved from this promising cryogenic separation technology (Andriani et al. 2014). As this technology is not yet widely used, further research is required to obtain reliable data on investment and operating costs. From the existing literature, the energy requirement seems to lie between 0.42 and $1 \mathrm{kWh} / \mathrm{Nm}^{3}$, which indicates prevailing uncertainties associated with this technology. Cryogenic separation is an eco-friendly process, and no chemical usage is involved. However, high energy is needed to run this technology. This technology also involves expensive investment, maintenance, and operation costs.

\section{Membrane separation}

Membrane separation is a method of separating components in solutions by rejecting undesired/unwanted substances and also allowing the remaining substances to pass via the membrane. The membrane can also change the solution composition based on relative permeation rates. Its performance is evaluated by the membrane's capacity to regulate, prevent, or improve permeation. A membrane cascade is used to enhance membrane performance. Membrane cascades with recycling are frequently utilized to attain a higher degree of separation. The separation method of a single-stage membrane consists of one membrane module or several such modules which are organized in parallel or series without recycling.

Membrane separation has numerous applications in industrial sectors, including nitrogen production from the air, hydrogen recovery with the use of ammonia plants, vapour recovery from processed gas streams, and biogas treatment and upgrading (Ramírez-Santos et al. 2018). Some new applications with successful commercial progress include dehydration of natural gas and air (Galizia et al. 2017). Intensive research and development efforts are being undertaken to broaden the range of uses for gas separation membranes. $\mathrm{CO}_{2}$ capture from industrial emissions and power plants is one of the relevant applications in the mitigation context of greenhouse gases.

Membrane separation occurs at the molecular level employing the fundamental rule of differential permeability of different molecules through a membrane (Yong and Zhang 2020). The constituent molecules of biogas can be arranged in order based on their permeation rates, where $\mathrm{CO}_{2}$ has the highest permeability and $\mathrm{CH}_{4}$ the lowest (Noroozi and Bakhtiari 2019). Categories of low and medium flow rates with high $\mathrm{CO}_{2}$ content, especially less than $300 \mathrm{Nm}^{3} / \mathrm{h}$, are suitable for membrane separation technology (Niesner et al. 2013). The driving forces behind membrane separation technology (Fig. 5) are operating temperature and pressure followed by sorption and diffusion coefficients, molecular size, electric charge, the difference in concentrations, and finally membrane construction material.

The sorption coefficient depends on the condensability, with larger molecules showing more condensability than smaller ones. In contrast, the diffusion coefficient is reversely proportional to molecular size. Therefore, the higher solubility of $\mathrm{CO}_{2}$ is dictated by its higher sorption coefficient and diffusion coefficient (Hu et al. 2019). Conventional membranes used in this technology exhibit a thousand times more preferential selectivity towards $\mathrm{CO}_{2}$ over $\mathrm{CH}_{4}$. Preferential infusion of $\mathrm{CO}_{2}, \mathrm{H}_{2} \mathrm{~S}$, and $\mathrm{O}_{2}$ leaves behind a gas stream saturated with $\mathrm{CH}_{4}$ and $\mathrm{N}_{2}$. Polymeric materials like cellulose acetates are chosen over non-polymeric materials for the manufacturing membranes on account of their high precision selectivity, affordability, easier production, excellent thermal and structural stability under high-pressure conditions, and rapid scalability (Selatile et al. 2018). Other organic polymerics, for instance, polycarbonates, polysulphones, polyimides, and polydimethylsiloxane, are also used for manufacturing membranes (Chen et al. 2015).

Membrane separation technology has recently gained much attention because of the advances in membrane nanotechnology which have been able to further increase the selectivity factors, therefore enhancing the biomethane recovery potential (Norahim et al. 2018). This mature technology currently represents only a $10 \%$ share of the worldwide market and is commercially used in two different 


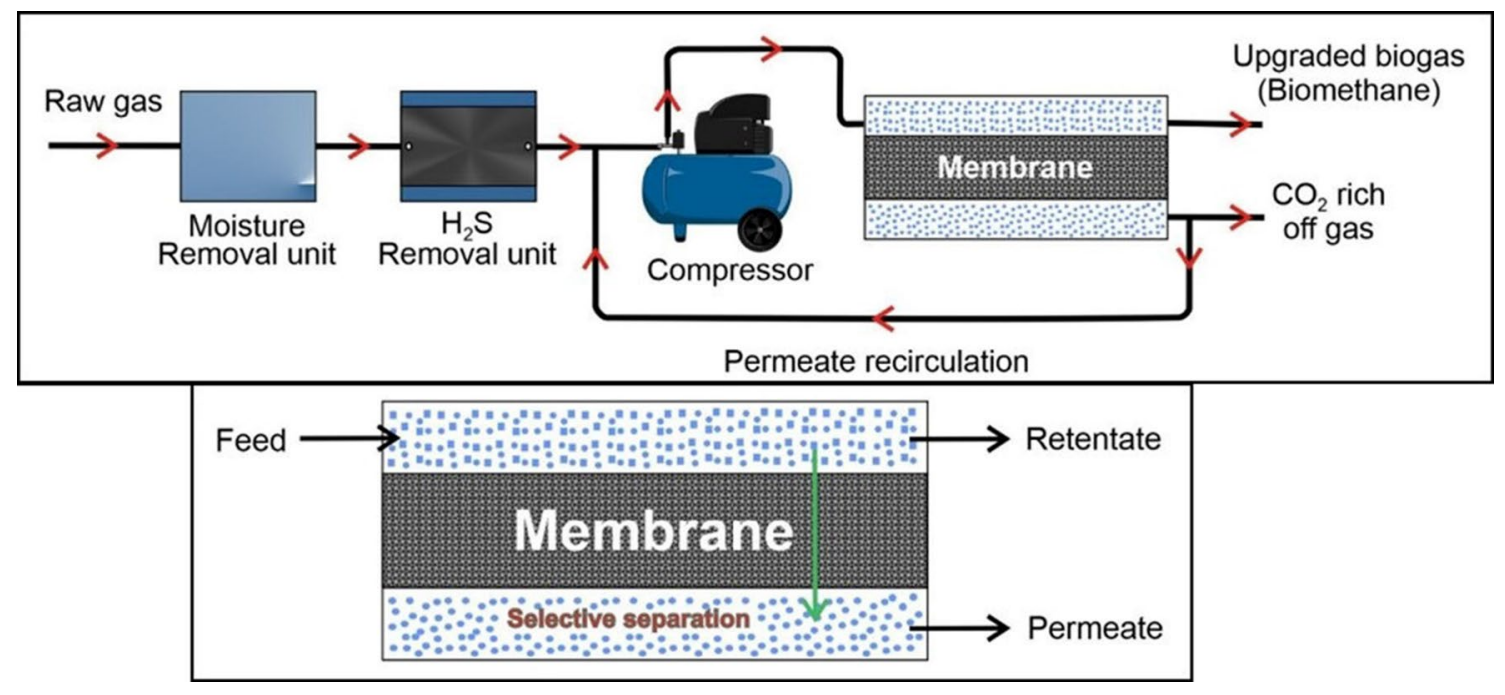

Fig. 5 Membrane separation of raw biogas, operation either as gasgas under high-pressure conditions, or gas-liquid under low-pressure conditions. In the gas-gas module, both sides have a gaseous state,

modalities: (1) gas-gas under high-pressure conditions; and (2) gas-liquid under low-pressure conditions (Thrän et al. 2014). In the gas-gas module, both sides have a gaseous state, whereas in the latter module, the gaseous $\mathrm{CO}_{2}$ and $\mathrm{H}_{2} \mathrm{~S}$ atoms diffuse into the fluid state on the opposite side of the membrane (Kim et al. 2021). Usually, in a gas-gas module, raw biogas is compressed with 20-40 bar pressure which results in accumulation of retentate at the inlet rich in biomethane at atmospheric pressure; over $97 \%$ pure biomethane can be produced through decompression to negative pressure levels by partially recycling the permeate saturated with $\mathrm{CO}_{2}$ and residual $\mathrm{CH}_{4}$ (Bauer et al. 2013b).

There are mainly two different arrangements of gas-gas modules currently available in the market: one involves single-pass membrane modules and the other multiphase membrane modules with interior alternative recycling systems (Hidalgo et al. 2020). The primary drawback of this technique is the low $\mathrm{CH}_{4}$ recovery rate due to the undesirable infusion of $\mathrm{CH}_{4}$ under high-pressure conditions. As a result, the highest $\mathrm{CH}_{4}$ recovery (92\%) can be obtained in a single-pass unit (Chen et al. 2015). On the other hand, the multistage arrangement can boost $\mathrm{CH}_{4}$ recovery from 80 to 99.5\%. In contrast, gas-liquid units operate at atmospheric pressure, where the raw biogas is separated from $\mathrm{CO}_{2}$ specific absorbent using a hydrophobic microporous membrane partition.

Raw biogas and absorbent flow towards each other in a counter cutter mode to facilitate biogas to liquid mass transfer (Rafiee et al. 2021). Alkanol amines and other limy solutions work best as absorbents in membrane separation technology (Ochedi et al. 2020). Amine-based solutions are the most efficient and can be regenerated by heating, thereby whereas in the gas-liquid module, the gaseous carbon dioxide and hydrogen sulphide atoms diffuse into the fluid state on the opposite side of the membrane

discharging isolated $\mathrm{CO}_{2}$ through desorption (Zhang et al. 2018). As the gas-liquid unit operates at atmospheric temperature, the construction and operating costs of this unit are logically less than the gas-gas unit. Also, the pure $\mathrm{CO}_{2}$ released from the system can be commercially sold. Singlephase gas-liquid or dual-phase gas-gas membrane separation configurations can yield a $98-99 \%$ biomethane purity level through continuous extraction of trace $\mathrm{CH}_{4}$ from the recirculating stream of raw biogas. Yet, with advanced setups that have an internal recirculation system for recovering residual $\mathrm{CH}_{4}$ from the flow, the highest possible purity level of $99.5 \%$ can be reached with this technology (Liemberger et al. 2017). In this case, units interconnected in series run the recycling of the exhaust gas from the previous unit; $\mathrm{CO}_{2}$ is removed from the very first unit so that the purity of the biomethane can be adjusted in the following units (Augelletti et al. 2017).

The membrane separation arrangement increases biomethane purity; however, its energy cost is higher (Chang et al. 2020) since two internal compression phases are required (Miltner et al. 2017). Technical availability of $\mathrm{CH}_{4}$ stays between 95 and $98 \%$ in biogas upgrading plants using the membrane separation technique (Casado-Coterillo et al. 2020). Membrane manufacturers guarantee 96-98\% purity for gas-liquid and multi-step gas-gas units, conversely, 92-94\% for single-pass gas-gas units ( $\mathrm{Lu}$ et al. 2018), and 10-25\% for off-gas permeate which needs further treatment (Andriani et al. 2014). With either increased pressure or a larger membrane surface area, $\mathrm{CH}_{4}$ concentration can potentially be further increased. Pre-conditioning of raw biogas to separate $\mathrm{H}_{2} \mathrm{O}, \mathrm{H}_{2} \mathrm{~S}, \mathrm{NH}_{3}$, and siloxanes by activated carbon filtration and subsequent compression is strongly suggested 
to prevent operating failures such as fast degradation and blockage of the micropores, thus prolonging the operational life of the system.

The major expense of the membrane separation technology is associated with the replacement of the activated carbon filter, condensation of contaminants (pre-conditioning); pre-compression of raw biogas which requires an electrical power supply ranging between 0.2 and $0.38 \mathrm{kWh} / \mathrm{Nm}^{3}$, and replacement of the membranes which typically have lifespans of 5-10 years (Bauer et al. 2013a). This technology involves higher maintenance costs, up to $4 \%$ more initial investment cost and 2-3\% of the installation cost than the other technologies currently available in the market (Barbera et al. 2019). Membrane separation is a simple process, easy to install and operate. It is also suitable for low gas flow rates, with no substantial increase in costings for small units. However, the membrane needs to be replaced within 1 to 5 years.

\section{Chemical technologies}

\section{Chemical scrubbing}

Identical to water/organic scrubbing, chemical scrubbing follows the same operating principles of a counter-current flow arrangement for biogas-liquid mass transfer. However, the setup and process of chemical scrubbing (Fig. 6) are much simpler and more developed, yielding much better performance based on the efficient utilization of absorbents, for instance, alkanol amines or aqueous lime solutions which have a high affinity towards $\mathrm{CO}_{2}$ (Gadikota 2020). A broad array of biogas flow rates can be used in chemical scrubbing technology although the preferred flow rate range is medium, varying from 500 to $1000 \mathrm{Nm}^{3} / \mathrm{h}$ (Niesner et al.

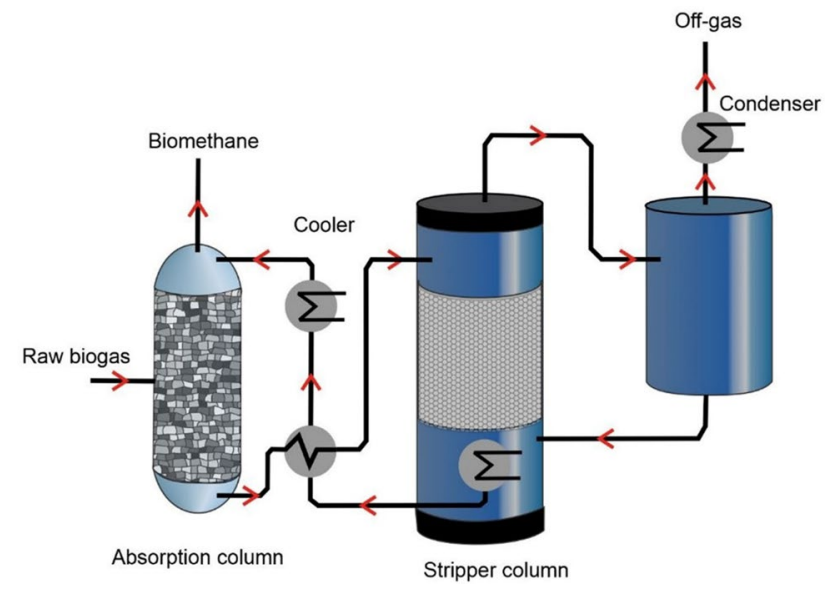

Fig. 6 Biogas chemical scrubbing, consisting of both an absorption and a stripper column. In this process, the stripping column is aided by a reboiler that supplies heat
2013). In contrast to other physical scrubbing solvents, chemical solvents are particularly advantageous when the $\mathrm{CO}_{2}$ concentration is low in raw biogas (Wang et al. 2020). The most prevalent amine scrubbing agent in recent times has been a concoction of methyl diethanolamine and piperazine (aMDEA) at a 4:7 aMDEA/CO $\mathrm{CO}_{2}$ mol ratio (Bauer et al. 2013a).

Chemical scrubbing comprises a combined configuration of both an absorption and a stripper column. The stripping column is facilitated by a reboiler that supplies heat at the temperature of $120-160{ }^{\circ} \mathrm{C}$ (Angelidaki et al. 2018). This setup is suitable for less complex process configurations than other physical scrubbing processes (De Guido et al. 2018). Simultaneously, due to the high $\mathrm{pH}$ condition of the amine-based solvents, biomass accumulation or eutrophication is not possible (He et al. 2019). Using the chemical scrubbing technology, boosted $\mathrm{CO}_{2}$ removal can be achieved because of the formation of intermediate compounds like $\mathrm{CO}_{3}{ }^{2-}, \mathrm{HCO}_{3}{ }^{-}$through the exothermic reaction among $\mathrm{CO}_{2}$ and other components available in the scrubbing solution (Ryckebosch et al. 2011). Improved solubility capacity of $\mathrm{CO}_{2}$ translates to lower requirements for process configurations, such as scope for compact upgrading facilities and less frequent recycling of reduced volume of solvent (Grim et al. 2020).

The chemical scrubbing technology can also be performed without using a stripper column. This is the case when sodium hydroxide $(\mathrm{NaOH})$ is used as a solvent, allowing for chemical regeneration. As an alternative to high energy consumption, the $\mathrm{NaOH}$ regeneration process can be exploited by the biogas upgrading unit via calcium carbonate $\left(\mathrm{CaCO}_{3}\right)$ precipitation as a beneficial by-product (Baena-Moreno et al. 2018). The key parameters affecting the $\mathrm{NaOH}$ regeneration are the molar ratio between $\mathrm{Na}_{2} \mathrm{CO}_{3}$ and calcium hydroxide $\mathrm{Ca}(\mathrm{OH})_{2}$, reaction temperature, and reaction time, which were analysed by Baena-Moreno et al. (2018) to assess the regeneration efficacies. The regeneration efficiencies of 53-97\% were achieved in the study by varying these parameters. The results demonstrated the technical viability of this process of biogas upgrading via $\mathrm{CaCO}_{3}$ production. However, the presence of $\mathrm{NaOH}$ in small quantities has no beneficial effect on the regeneration process as well as reduces regeneration efficiency because of the common ion effect.

The biogas upgrading unit can also benefit from the $\mathrm{NaOH}$ regeneration process using the calcium-magnesium carbonate compound. The $\mathrm{NaOH}$ regeneration process is found as an alternative to physical processes, whose high energy consumption poses economic constraints. In a biogas upgrading unit, the impact of calcium-magnesium carbonate compound on the regeneration efficiency was studied by Baena-Moreno et al. (2019a). Noteworthy effects were seen when $\mathrm{Ca}(\mathrm{OH})_{2}$ was used as a precipitating agent. 
Indeed, a high regeneration efficiency of $97 \%$ was achieved using $70{ }^{\circ} \mathrm{C}$ reaction temperature. However, under the same operational settings, significant variations were found when magnesium hydroxide $\left(\mathrm{Mg}(\mathrm{OH})_{2}\right)$ was used as the precipitating agent. The results reveal that the efficiency of calcium in aqueous carbonation studies is substantially greater than that of magnesium. Furthermore, calcium resulted in higherquality products to keep the overall economy of the process affordable.

Minimal pressure is needed to run the chemical scrubbing process, only 1-2 bar during absorption and around 1.5-3 bar during the process of stripping (Struk et al. 2020) which as a whole results in reduced power consumption expense. Therefore, the atmospheric pressure (1.01325 bar) can be used for operating this technology without stripping. After scrubbing, the absorbent rich in $\mathrm{CO}_{2}$ and $\mathrm{H}_{2} \mathrm{~S}$ is pumped out of the absorption column and routed to the desorption column through heat exchange for the regeneration of the spent solvent. The reboiler attached to the desorption column supplies heat for the reaction of desorbing $\mathrm{CO}_{2}$ from the scrubbing agent through the disruption of chemical bonds created at the previous step. In addition, this heating process also creates a stream of vapour which functions as a stripping fluid in the process. The vapour stream is then cooled down in a condenser and recirculated so that the $\mathrm{CO}_{2}$ entrapped in the steam can be released and recovered (Basso et al. 2021).

The advanced chemical scrubbing technology could only capture $22 \%$ of the global market because the absorbent regeneration process requires temperatures as high as $120^{\circ} \mathrm{C}$ to $160{ }^{\circ} \mathrm{C}$ which significantly increases energy use (Thrän et al. 2014). The $\mathrm{CH}_{4}$ recovery rates of 99.5-99.9\% can be accomplished with chemical scrubbing which is attributable to the excessively low solubility of methane in amine-based solvents (Cheng et al. 2019). Even though a $\mathrm{H}_{2} \mathrm{~S}$ concentration of up to 300 ppmv can be managed in this process, pre-removal of $\mathrm{H}_{2} \mathrm{~S}$ using activated carbon filters is the best method to avoid toxic building up in the amine reagents. At the same time, prior removal is recommended because if $\mathrm{H}_{2} \mathrm{~S}$ is absorbed, desorption from the solvent post-scrubbing requires more energy.

Degradation of amine by $\mathrm{O}_{2}$ poisoning, successive foaming, salt precipitation, and high corrosion rates of the setup are the dominant functioning difficulties of chemical scrubbing technologies (Zhang et al. 2019). Still, the investment required to tackle these issues is negligible: $3 \mathrm{mg} \mathrm{Nm}^{-3}$ per compound and the cost of $0.12-0.15 \mathrm{kWh} / \mathrm{Nm}^{3}$ power for condensing raw biogas and pumping solvent can be considered moderate (Bauer et al. 2013b). Amine-based solvent regeneration typically requires more than $0.55 \mathrm{kWh} / \mathrm{Nm}^{3}$ power which is responsible for the highest costing chemical scrubbing method. Additionally, as the scrubbing agent is toxic to the environment and humans, the requirement to treat the waste materials from the upgrading plants makes the method even more expensive.

Due to the issues mentioned above and despite having many other advantages, this technology is not preferred by many biogas upgrading plants. The main surveyed studies on physical and chemical technologies for biogas upgrading are given in Table 2 which compares them by emphasizing their raw biogas consumption, clean biogas consumption, heat consumption, heat demand, operational cost, $\mathrm{CH}_{4}$ losses and recovery, pre-purification, $\mathrm{H}_{2} \mathrm{~S}$ co-removal, $\mathrm{N}_{2}$ and $\mathrm{O}_{2}$ co-removal, operation pressure, and outlet pressure. Overall, the chemical scrubbing technology offers more than $99 \%$ of the efficiency of $\mathrm{CH}_{4}$ recovery, and it can be operated at low-pressure conditions. However, this process possesses a risk of brackish coagulation and foaming.

\section{Biological technologies}

\section{Chemoautotrophic methods}

The ability of chemoautotrophic methanogenic microbes to convert $\mathrm{CO}_{2}$ to $\mathrm{CH}_{4}$ is the basis of chemoautotrophic biogas upgrading. Methanogenesis techniques are conventionally utilized for the methane enrichment and effective removal of $\mathrm{H}_{2} \mathrm{~S}$ from biogas sourced from landfills or anaerobic digesters (Bharathiraja et al. 2018). For instance, one bacterium often called M. thermoautotrophicum is capable of elevating the amount of biomethane in the raw biogas from 60 to $96 \%$ while keeping the $\mathrm{H}_{2}$ and $\mathrm{H}_{2} \mathrm{~S}$ concentrations negligible. Injecting $\mathrm{H}_{2}$ from the outside into the system to biologically convert $\mathrm{CO}_{2}$ to $\mathrm{CH}_{4}$ is used both in producing biomethane and in capturing high volume emissions of $\mathrm{CO}_{2}$ from electronics manufacturing facilities (Zabranska and Pokorna 2018).

Nonstop supply of $\mathrm{H}_{2}$ into the system can result in a 95\% $\mathrm{CH}_{4}$ concentration in the upgraded biogas (Luo and Angelidaki 2013a). Microbes such as methanobacterium, methanospirillum, and methanococcus are constantly found to support bioconversion of $\mathrm{CO}_{2}$ to $\mathrm{CH}_{4}$ upon introduction of $\mathrm{H}_{2}$ inside anaerobic digesters (Zabranska and Pokorna 2018). In a similar manner, pushing $\mathrm{H}_{2}$ into the bioreactor is shown to escalate microbial activity. The main constraint of the chemoautotrophic biogas upgrading technology lies in the fact that the current structure of anaerobic reactors is not designed to take full advantage of the gas-liquid mass transfer for up-scaling.

There are some risks such as deterioration of the structure and reduction in the efficiency of anaerobic flocs (Jiang et al. 2021). Even at a smaller scale, the biomethane composition achieved so far is not that promising. Additionally, due to the requirement for bulk quantities of $\mathrm{H}_{2}$, this technology must make sure that $\mathrm{H}_{2}$ is sourced sustainably, for example, 


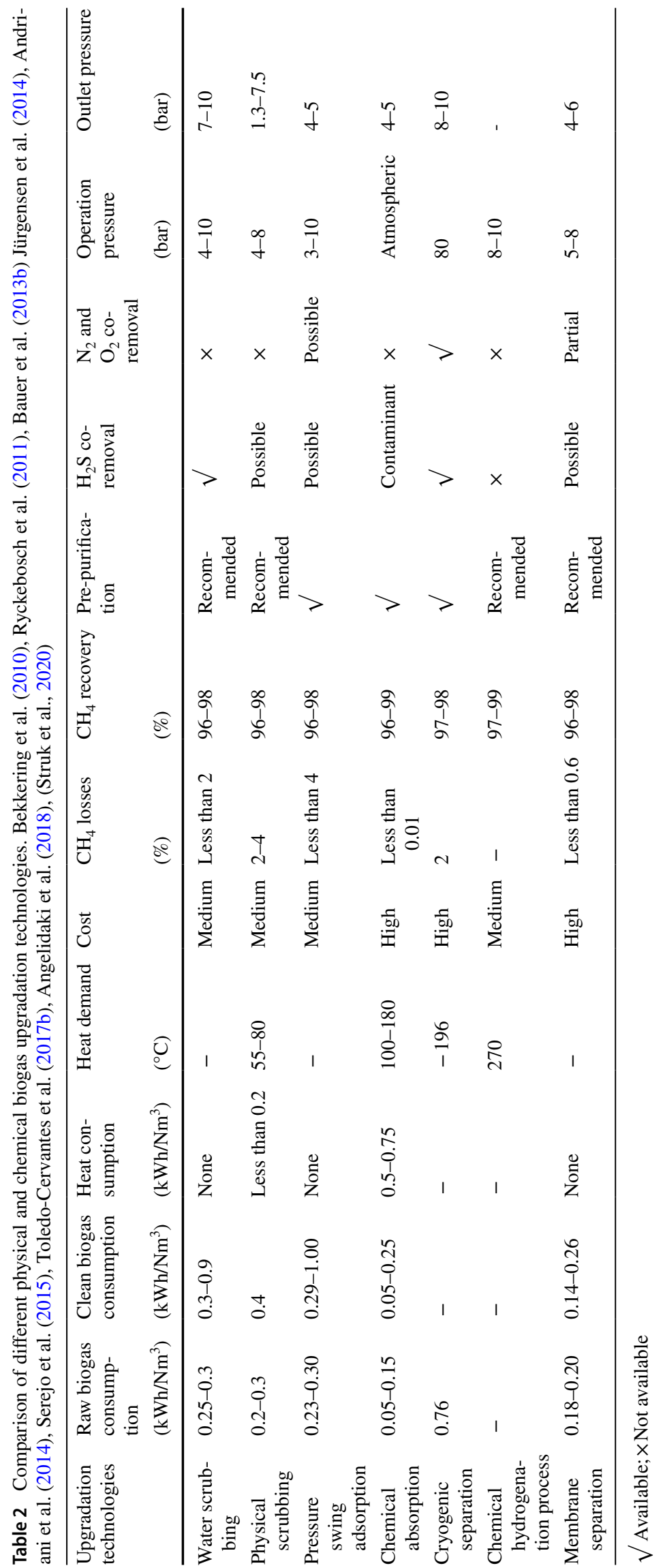


through electrolysis using an excess of electricity or from an adjacent facility where $\mathrm{H}_{2}$ is produced as a by-product of treating acidic wastewaters (Zhuang et al. 2020). At the same time, proper safety measures and operational mechanisms need to be in place to carefully control the risk of introducing the highly inflammable $\mathrm{H}_{2}$ gas into any anaerobic bioreactor.

\section{Photosynthetic biogas upgrading}

The photosynthetic potential of microalgae has been utilized to design photosynthetic biogas upgrading technology where $\mathrm{CO}_{2}$ is sequestered into microalgae biomass in any microalgal cultivation broth as shown in Fig. 7. Eukaryotic microalgae and prokaryotic cyanobacteria can remove $\mathrm{CO}_{2}$ from biogas through bioconversion in a photolysis reaction (Deviram et al. 2020). Roughly, $1.8 \mathrm{~g} \mathrm{CO}_{2}$ is needed to produce 1 gm microalgae. Although a $5 \% \mathrm{CO}_{2}$ concentration usually inhibits algal growth, extensive research has successfully identified some species which can withstand a $\mathrm{CO}_{2}$ concentration in raw biogas as high as 60\% (Zabed et al. 2020).

It has been found that some microalgae such as Chlorella's growth is suppressed due to the presence of a $\mathrm{H}_{2} \mathrm{~S}$ content higher than 100 ppmv (Kao et al. 2012). On the other hand, due to the concurrent presence of some sulphate oxidizing bacterial species and spontaneous oxidation of $\mathrm{H}_{2} \mathrm{~S}$ into sulphate by dissolved oxygen (DO), $\mathrm{H}_{2} \mathrm{~S}$ does not reach the inhibitory level (Bahr et al. 2014). $\mathrm{CH}_{4}$ also does not exert any negative impact on microalgal growth up to a concentration of $80 \%$. This is because $\mathrm{CO}_{2}$ is characteristically less soluble and inert in microalgal cultivation broth.

The efficiency of $\mathrm{CO}_{2}$ removal is subject to external factors like availability of sunlight, $\mathrm{pH}$, and concentration of dissolved oxygen (DO) in the cultivation of broth (Alami et al. 2021). Thus, the optimal conditions for microalgal growth are: (1) solar radiation levels at around 200 to 400 $1 \mathrm{Em}^{-2} \mathrm{~s}^{-1}$ (Tredicid 2010); (2) a temperature of $15^{\circ} \mathrm{C}$ to $25{ }^{\circ} \mathrm{C}$, with some microalgae, namely Chlorella, breeding well even at $30{ }^{\circ} \mathrm{C}$ to $35^{\circ} \mathrm{C}$; (3) a pH of 7-8, though for some cyanobacterial species a $\mathrm{pH}$ of 9-10 is optimal for maximum $\mathrm{CO}_{2}$ bioconversion given its acidic nature (De Godos et al. 2014); (4) a DO volume below $1 \%$ because of its explosive nature at higher concentration levels (Bahr et al. 2014); and finally (5) a gas retention time 0.03 to $0.3 \mathrm{~h}$ for outdoor bioreactor setups and 0.7 to $96 \mathrm{~h}$ for indoor setups.

Up to $80 \% \mathrm{CO}_{2}$ sequestration with $90 \%$ biomethane production is achieved using photosynthetic biogas upgrading technology, though 6-9\% $\mathrm{N}_{2}$ in the upgraded biomethane is still a technical limitation that requires further development. Photosynthetic biogas upgrading is one of the top environment-friendly technologies of the available biogas upgrading technologies due to its $\mathrm{CO}_{2}$ capturing ability. It contributes positively towards reducing $\mathrm{CO}_{2}$ released into the atmosphere. Microalgal biomass produced in this process can be further utilized as feedstock for the biofuel industry and other valuable new-generation commodities such as pharmaceuticals, cosmetics, high protein food items, and so on (Alcántara et al. 2013). In addition,

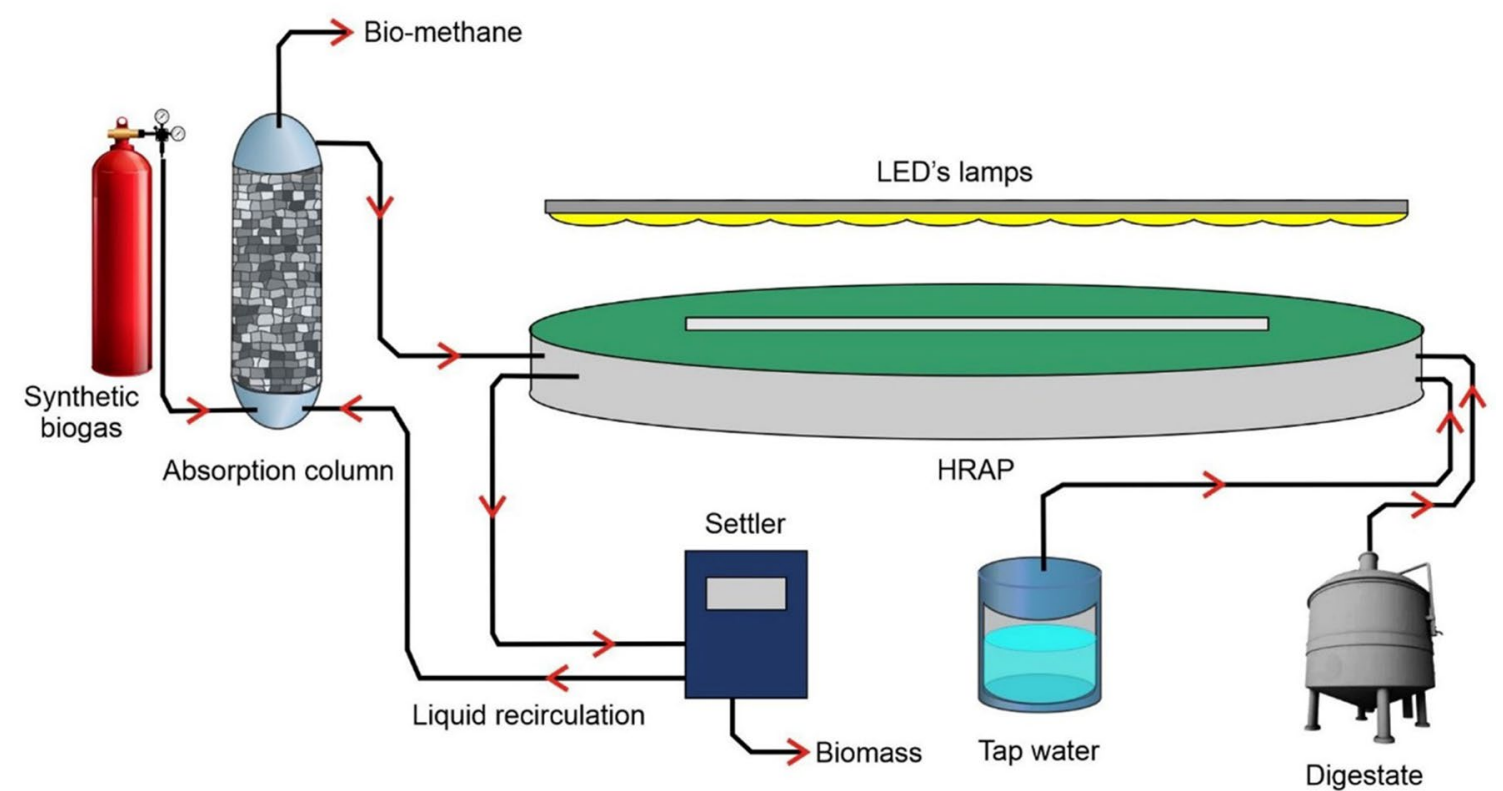

Fig. 7 Photosynthetic biogas upgrading process. In this process, carbon dioxide is sequestered into microalgae biomass in any microalgal cultivation system. This process is environment friendly due to its $\mathrm{CO}_{2}$ capturing ability. LED: light-emitting diodes. HRAP: high-rate algal pond 
residual nutrients in the anaerobic digester are spontaneously consumed by the microalgae community; hence, the mitigation of possible eutrophication in digestors is a positive side effect of this technology.

\section{In situ desorption}

In situ desorption technology has been around for around 20 years. However, it is still under development due to the lack of full-scale implementation. The substantially greater solubility of $\mathrm{CO}_{2}$ over $\mathrm{CH}_{4}$ in water is the basis for the in situ enrichment of $\mathrm{CH}_{4}$. The operational setup includes an anaerobic digester interconnected with an external desorption unit as shown in Fig. 8a. In this process, sludge is transported to an aerated desorption column from the anaerobic digestor (Sarker et al. 2018). Air or $\mathrm{N}_{2}$ flowing in counter-current mode easily dissolves $\mathrm{CO}_{2}$ from the sludge in the desorption unit. Desorbed sludge is then pumped back into the digestor to reabsorb additional $\mathrm{CO}_{2}$, and the sludge is also continuously recycled in the desorption column. It is possible to easily strip out $\mathrm{H}_{2} \mathrm{~S}$ together with dissolved $\mathrm{CH}_{4}$ and $\mathrm{CO}_{2}$ from the recirculating sludge by applying a large amount of air or $\mathrm{N}_{2}$, which causes a total reduction in the concentrations of $\mathrm{H}_{2} \mathrm{~S}$ and $\mathrm{CO}_{2}$ in the raw biogas (Nordberg et al. 2012). However, biomethane yield is relatively low because of $\mathrm{CH}_{4}$ losses ranging from 2 to $8 \%$. In a pilot-scale configuration, small-sized anaerobic digestors $\left(15 \mathrm{~m}^{3}\right.$ to 19 $\mathrm{m}^{3}$ ) interconnected to desorption columns with a capacity of
$90 \mathrm{~L}$ to $140 \mathrm{~L}$ provided around $87 \% \mathrm{CH}_{4}$ purity with associated losses of $8 \%$.

Usually, $\mathrm{CO}_{2}$ becomes dissociated in the digestor and yields $\mathrm{H}+$ and $\mathrm{HCO} 3$. This process maintains the optimal bicarbonate buffer concentration in the system (Silva et al. 2019). However, as in this technology $\mathrm{CO}_{2}$ is readily utilized, the concentration of $\mathrm{H}+$ is proportionally reduced, while the $\mathrm{pH}$ level is elevated. Operational parameters, mainly $\mathrm{pH}$, should be monitored and controlled regularly for the smooth operation of in situ desorption technology. To alleviate $\mathrm{pH}$-related challenges, introducing acidic waste into the bioreactor for co-digestion has proven beneficial to keeping the $\mathrm{pH}$ level within the optimal limit (Luo and Angelidaki 2013a). On the other hand, it has been found that a higher content of $\mathrm{CO}_{2}$, primarily in the form of bicarbonate, promotes enhanced $\mathrm{CO}_{2}$ desorption due to a quasi-selective separation potential over $\mathrm{CH}_{4}$. Furthermore, the airflow rate is considered another major operational determinant of efficient biogas upgrading using this technology.

Impurities contained in upgraded biomethane can be lowered significantly using a stronger airflow into the desorption column, but $\mathrm{CH}_{4}$ losses will be quite high. $\mathrm{CH}_{4}$ purity can be minimized while achieving maximum $\mathrm{CO}_{2}$ removal by increasing the sludge retention time in the desorption column (Muñoz et al. 2015). To sum up, as biological biogas upgrading technologies are still being run experimentally in lab-based setups or on a pilot scale,

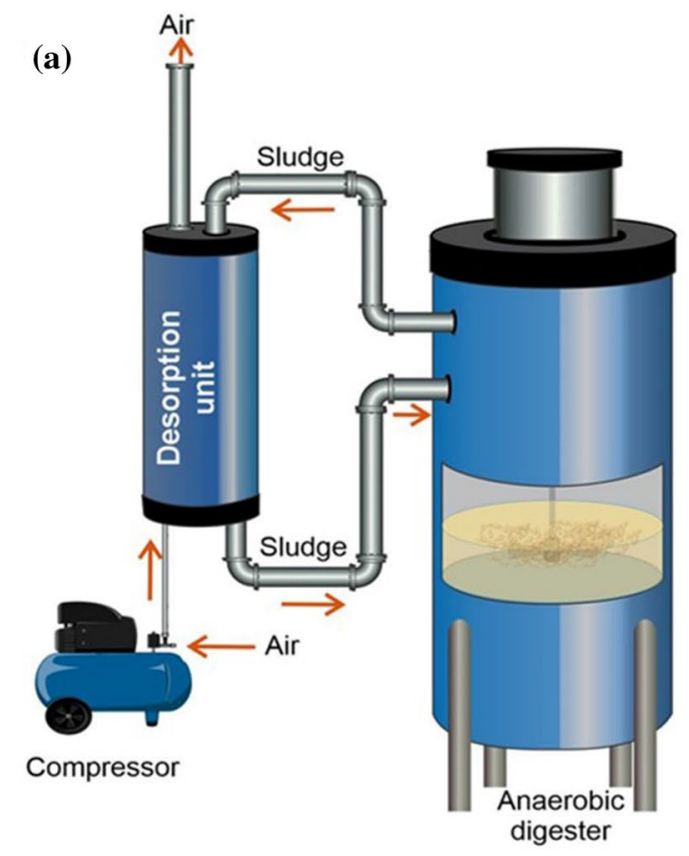

Fig. 8 Biogas upgrading by $\mathbf{a}$ in situ desorption $\mathbf{b}$ ex situ desorption. In the in situ process, an anaerobic digester is interconnected with an external desorption unit, while in the ex situ process, an anaero-

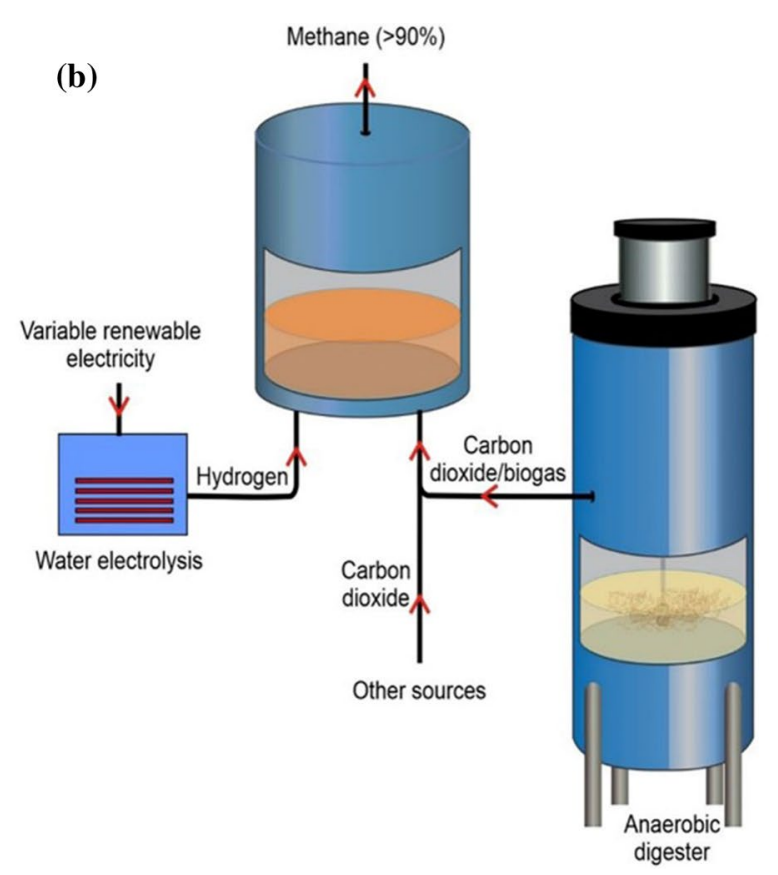

bic digester is interconnected with the reactor where hydrogen from a renewable source is injected 
accurate data on investment and operating, identification of limitations and challenges at full-scale operation are still ambiguous for these technologies. The main technical challenge of in situ desorption technology is the $\mathrm{pH}$ level reaching above 8.5 which is inhibitory to methanogenesis. A pH of 8.5 is the upper limit for both mesophilic and thermophilic standard bioconversion of $\mathrm{CO}_{2}$ to biomethane (Bassani et al. 2015).

\section{Ex situ desorption}

The ex situ biogas upgradation principle depends on the provision of carbon dioxide from external sources and hydrogen in an anaerobic reactor, which contributes to their eventual conversion to methane (Bassani et al. 2017). The ex situ process (Fig. 8b) can manage high concentrations of influent gases, thereby decreasing the gas retention time to $1 \mathrm{~h}$, which minimizes the size of the biogas upgrader. The biogas efficiency improvement of this technology will result in a final methane content of $79 \%$ to $98 \%$, depending heavily on the type of reactor used (Angelidaki et al. 2018). The low gas-liquid mass transfer rate remains the technological challenge of this technology.

The ex situ biogas upgradation process has several benefits compared to the in situ approach, as shown in Table 3. The table summarizes the main studies surveyed to compare in situ and ex situ technologies for biogas upgrading in terms of the batch reactor, trickle-bed reactor (TBR), fixed bed reactor (FBR), biofilm plug flow reactor (BPFR), up-flow reactor (UFR), bubble column reactor (BCR), gas retention time (GRT), gas recirculation, and temperature. It is found that the mature technologies, many of which are physical and chemical upgrading technologies, have reached nearoptimum technical and economic feasibility, but are still highly energy and resource-intensive. Biological methods are explored less, despite showing huge potential in terms of techno-economic feasibility. They are also found environment friendly, and no chemical is required. However, this process is limited for large-scale operations, and the $\mathrm{pH}$ of the gas should be regularly monitored and controlled.

\section{Techno-economic analysis of biogas upgrading technologies}

Practically, the energy consumption of a particular energy application is distinctive. Biogas upgrading and cleaning technologies have been the subject of several reviews and literature studies throughout the years, where the primary focus of the majority of the studies has been on technologi$\mathrm{cal}$ and economic feasibility evaluation of the technologies (Chaemchuen et al. 2016; Lombardi and Francini 2020; Morero et al. 2017; Qyyum et al. 2020; Sahota et al. 2018;
Sheets and Shah 2018). The upgrading technologies assessed by most researchers are criticized for being costly in terms of large-scale implementation, and thus the focus of their recommendations has been on reducing the cost of operating such technologies. For example, the upgrading technologies assessed by Sahota et al. (2018) generate high operating costs and are energy-intensive, which restrict the opportunities to scale up these technologies. Hybrid technologies have been recommended by the authors to overcome the challenges of upgrading technologies.

Among all the parameters affecting the overall energy efficiency of the complete biogas upgrading process, the loss of $\mathrm{CH}_{4}$ is the most significant. The pressure swing adsorption process has a slightly lower energy consumption than water scrubbing (WS) but consumes much more energy than the chemical adsorption process (Kohlheb et al. 2020). The energy consumption required by the chemical adsorption process is about $15 \%$ less than the water scrubbing process (Vilardi et al. 2020). The energy consumption of microalgal photosynthesis was investigated in a study (Xu et al. 2019) where it was reported that this process was significantly more efficient than the other treatments, although verifying this conclusion without further details was believed to be difficult. The energy-saving aspect of the biological upgrading method was also evaluated with hydrogenotrophic methanogens. However, this evaluation was claimed to be difficult because $\mathrm{H}_{2}$ was required by the technology, given that the energy utilization was minimum.

Many researchers have looked into methods to lower $\mathrm{CH}_{4}$ losses and energy consumption in a bid to reduce cost. Morero et al. (2017) found water to be the simplest and most robust solvent for use in biogas upgrading processes compared with diglycolamine and dimethyl ethers of polyethylene glycol as it allowed the greatest $\mathrm{CH}_{4}$ recovery and $\mathrm{CO}_{2}$ capture with lower energy consumption. Similarly, in a techno-economic and environmental assessment of five upgrading technologies from biogas to biomethane, amine scrubbing exhibited the best environmental outcome because of its lower electricity use and $\mathrm{CH}_{4}$ loss (Lombardi and Francini 2020). However, the selection of an upgrading technology is more likely to be affected by cost-effectiveness. For instance, high-pressure water scrubbing was found to be more cost-effective for small plants, while potassium carbonate scrubbing showed the highest net present value for large plants (Lombardi and Francini 2020).

In most cases, the cost associated with the building where such upgrading processes are located is excluded. There is also no data available related to the cost associated with the processes that are involved in the biological and in situ upgrading methods. The investment costs related to biogas upgrading technologies have not changed much in a decade (Miltner et al. 2017). The operating and maintenance costs related to biogas upgrading plants mostly only include the 


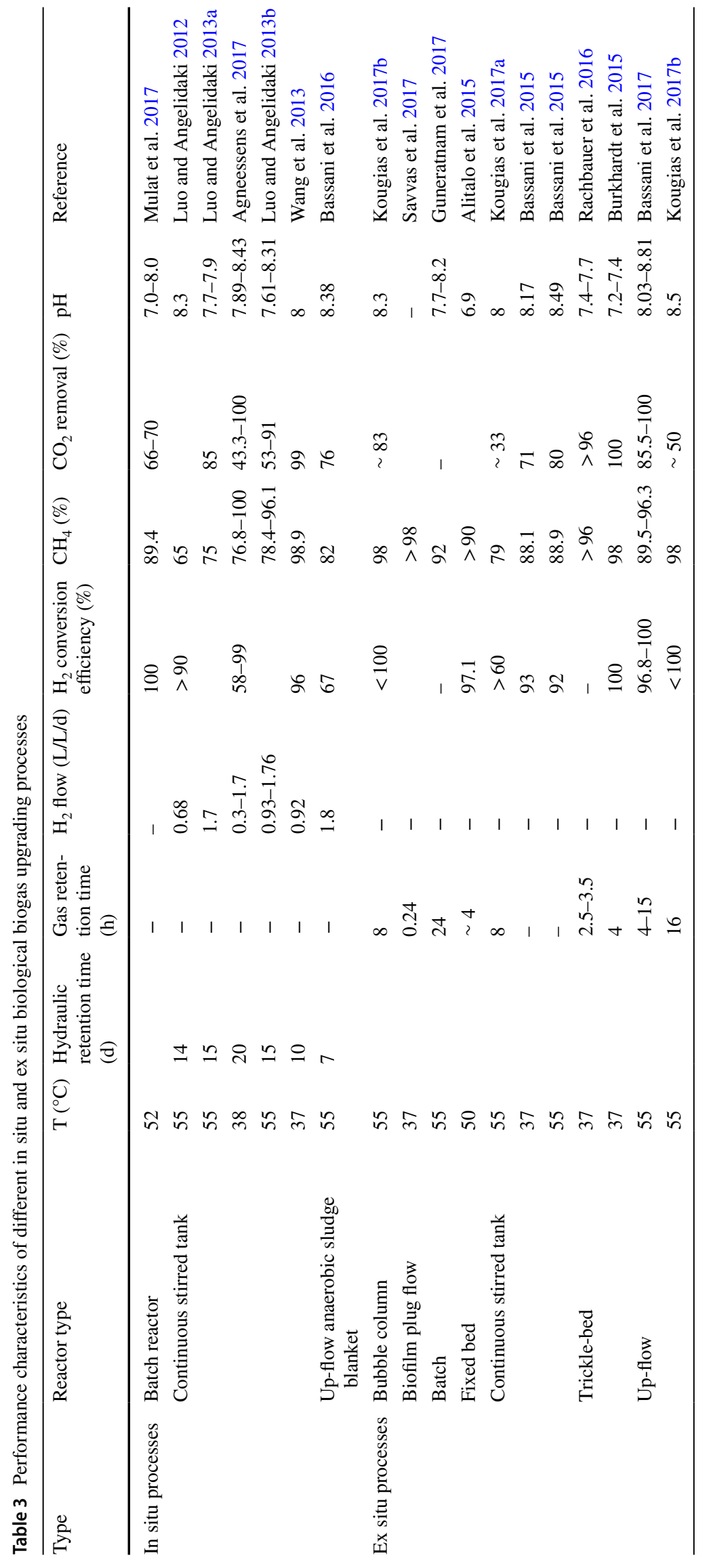


electricity, labour, water, and chemical costs based on the upgrading technology and relevant maintenance methods. Cryogenic technology generally has an increased operational and maintenance cost due to its low productivity. However, despite a high energy efficiency, the chemical absorption technology was also reported to have high operation and maintenance costs, specifically for large-sized plants. These results should be further confirmed by conducting more studies.

Costs may become less important when selecting appropriate technology, especially when specific biogas quality and site requirements are prioritized. Transportation of the biogas to the utilization sites also has great potential for cost reduction. To mitigate the costs and technological requirements of transporting biomethane, Qyyum et al. (2020) suggested liquefaction of biomethane, particularly emphasizing the benefits of nitrogen expander-based liquefaction processes attributed to their simplicity and low investment costs. In the techno-economic analysis undertaken by Sheets and Shah (2018), it was found that compressed natural gas (bio-CNG) generation had the highest rate of return, followed by refined biogas, while thermochemical methanol and biological methanol production had negative net present values. They concluded that improvements to the $\mathrm{CH}_{4}$ oxidation rate in the methanotrophs and methanol tolerance could reduce the cost of biological conversion. Khan et al. (2017) also recommended the biogas conversion to bio-CNG as a vehicle fuel because of its lower environmental impact. Reducing the loading time and input from the compressor and increasing the load mass to the cylinders of the vehicle are suggested as means to improve the efficiency of bioCNG storage systems.

The maintenance cost and energy demand to upgrade raw biogas are the key factors that are usually considered while selecting any upgrading technology. This is mainly because the maintenance cost is dependent on the operational expense of each process. Also, the regeneration energy of some of the methods makes the process costly and variable. The capital cost increases depending on the operating and management costs of individual upgrading technology. The investment and maintenance costs of biogas upgrading technologies are given in Fig. 9 (Kadam and Panwar 2017; Singhal et al. 2017; Vrbová and Ciahotný 2017). These costs are mostly based on the selected technology, the standard of biogas (raw), expected product standard, and essentially, the plant capacity. Generally, the upgrading technologies have quite similar capital investment costs which decrease only with plant capacity. Studies show that the financing of various upgrading technologies is remarkably dependent on the individual plant's capacity. Plants with a lower capacity, ranging from 0 to $100 \mathrm{Nm}^{3} / \mathrm{h}$, have an increased fixed investment cost and vice versa (Khan et al. 2017). Additionally, it has also been noted that different membrane materials and pressure regulation result in high energy variations.

Membrane separation, organic physical methods and water scrubbing are some of the popular technologies as their maintenance cost is low. Additionally, some studies have outlined that membrane separation, pressure swing adsorption (PSA), amine, and water scrubbing currently number among the leading biogas upgrading technologies. According to some reports, even some years back, the membrane separation method was reviewed as a big-budget and not well-established technology. However, recently, it has been gaining rapid market value and interest due to the accessibility of specific and low budget materials. The membrane-based biogas upgrading technology has shown an increasingly positive trend, and the units on the membrane are also found at low waste production for small biogas upgrading technologies.
Fig. 9 Investment and maintenance costs of various biogas upgrading technologies for $1000 \mathrm{~m}^{3}$ volume, modified after (Kadam and Panwar, 2017; Kapoor et al., 2019; Khan et al., 2017). Chemical swing adsorption showed higher capital and maintenance costs, while water scrubbing technology contributed to the lowest investment cost

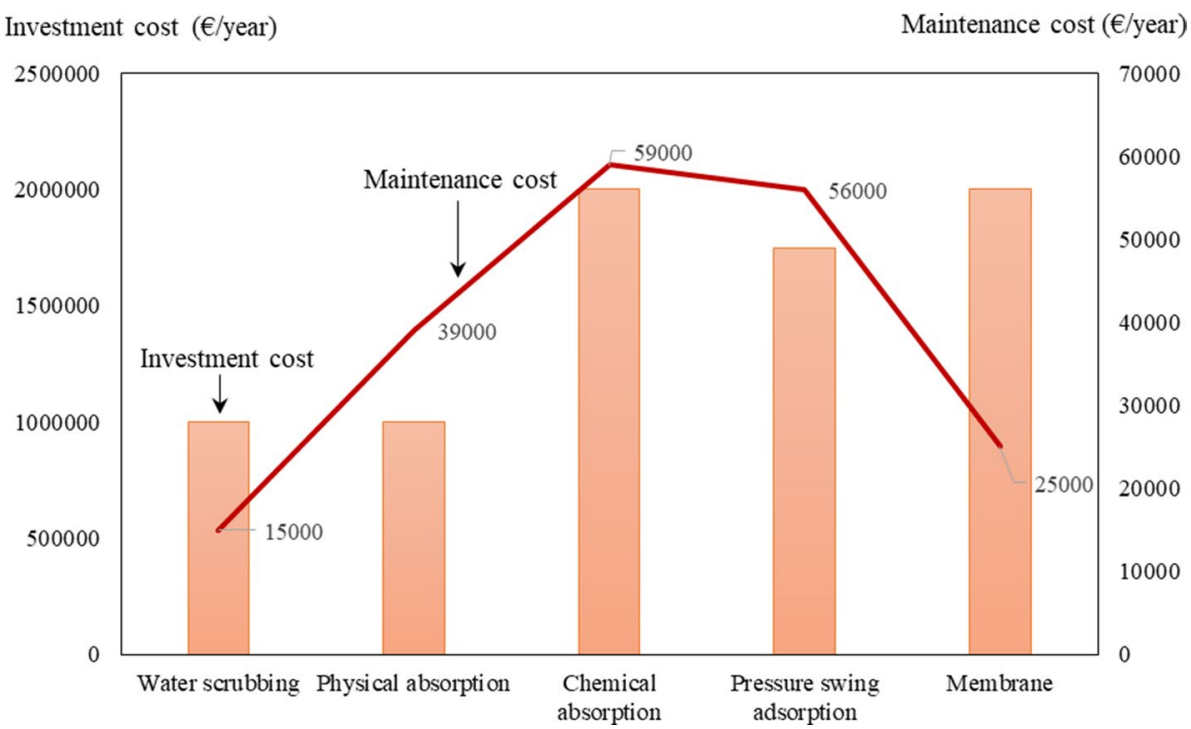


Over the past 10 years, biogas production increased significantly in Europe and has also been predicted to increase to 40.2 Mtoe in 2030 (Axelsson et al. 2012). Contributions from European countries alone were predicted to increase the global biogas market from $\$ 124$ billion in 2010 to $\$ 217$ billion in 2016. Even though it has been many years since technologies like water scrubbing, amine scrubbing, and PSA originally evolved, much research has been carried out to make them efficient. The studies include optimizing the water scrubber process to minimize the freshwater demand, advancing PSA to reduce valves with expensive pressure, using absorbent materials with high performance and low cost, and lastly, developing an amine process with a costefficient and convenient regeneration process for amine solution.

Cryogenic upgrading is the best technology for liquefied biogas (LBG) production; however, it is yet to become available for extensive commercial operations. Cryogenic separation requires the use of several devices and equipment which makes it a less suitable choice for biogas upgrading, resulting in reduced market popularity in the biogas development sector (Khan et al. 2017). Though optimistic views suggest that this technology could take a large portion of the market share if the functional and economic problems are resolved. Amine scrubbing is a well-known traditional biogas upgrading method mainly because of its low methane release functionality and its potential to deliver high-purity infinite methane products. However, recent technologies are also capable of upgrading biogas via biological methanation, a process in which the $\mathrm{CO}_{2}$ present in biogas is combined with $\mathrm{H}_{2}$ to generate renewable methane.

A study was conducted by Vo et al. (2018) to investigate biogas upgrading in three particular scenarios: upgrading by amine scrubbing; by amine scrubbing with $\mathrm{CO}_{2}$ run to ex situ biological methanation; and only by ex situ methanation. The results indicated that the lowest selling price per $\mathrm{m}^{3}$ of renewable methane for the three scenarios were $€ 0.76$, $€ 1.50$, and $€ 1.43$, respectively, given that the power generation cost to generate $\mathrm{H}_{2}$ was $€ 0.10$ per $\mathrm{kWh}$ and the cost for silage production was $€ 27 / \mathrm{t}$. It has been observed from these results that injecting biogas directly to the methanation reactor seems to be economically more beneficial than taking $\mathrm{CO}_{2}$ out of biogas and releasing it to the methanation process. Also, it has been established that the selling price for renewable methane in the first scenario is significantly lower than the others, suggesting that the expense related to $\mathrm{H}_{2}$ is a vital indicator in deciding the cost-effectiveness of renewable methane.

Besides the investment and operational costs for methanation and biological processes, the cost associated with the electrolysis of hydrogen is also considered. It was expected that the expenditure for the methanation plant was somewhere between $€ 652$ and $€ 785 / \mathrm{kW}$, and its operating expenses were around 4\%. However, assumptions about the related costs for the biological process could not be made as the technique was still under development (Adnan et al. 2019). In another study (Lombardi and Francini 2020), when five leading biogas upgrading technologies, high-pressure water scrubbing (HPWS), amine scrubbing, potassium carbonate scrubbing (PCS), pressure swing adsorption, and membrane permeation were compared based on economic and environmental viewpoints through life cycle assessment and costing methods, it was seen that electricity consumption was a significant parameter which controlled the results. For small-sized plants, HPWS proved to be slightly more economically friendly in comparison with others, whereas for large-sized plants, PCS demonstrated the maximum net value.

\section{Biogas utilization}

Biogas is typically a composition of about $50-70 \%$ methane, $25-45 \%$ carbon dioxide, $1-5 \%$ hydrogen in addition to a minute number of other gases like ammonia, water vapour, hydrogen sulphide, and halides. According to innovative and efficient strategies, managing and utilizing biogas are highly desirable for producing sustainable electrical power, but utilizing it for heating or lighting purposes is considered inefficient and the cause of pollution. Researchers are now prompted towards focussing on energy generation from minimal carbon sources through modern eco-friendly technology due to the increased value of petroleum and large-scale use of fossil fuels associated with greenhouse emissions (Siddiki et al. 2021).

Biogas is currently known as a field of vigorous research and progress and has been given a high priority as it is a feasible substitute to fossil fuels (Yentekakis and Goula 2017). As mentioned earlier, biogas contains small quantities of other gases except $\mathrm{CO}_{2}$ which are considered impurities and should be removed to upgrade the biogas before utilizing it. The concentration of impurities is dependent on the type of biogas source. Though it is recommended to remove impurities of the biogas depending on the requirements of each utilization process, biogas can also be used in the raw form without upgrading. Certain factors like resource availability, utilization of biogas, and investment costs need to be considered when selecting an upgrading technology (Raboni and Urbini 2014). Generally, the utilization of biogas occurs in two main ways, utilization of biomethane and $\mathrm{CO}_{2}$. The potential utilization of biogas is shown in Fig. 10.

\section{Fuels for vehicles}

The application of upgraded biogas for vehicle fuel has created interest in the transport sector worldwide. From an 
Fig. 10 Applications of biogas in different sectors, modified after (Ullah Khan et al., 2017). Biogas can be used as a source of heat, power and fuel by using appropriate upgradation technologies

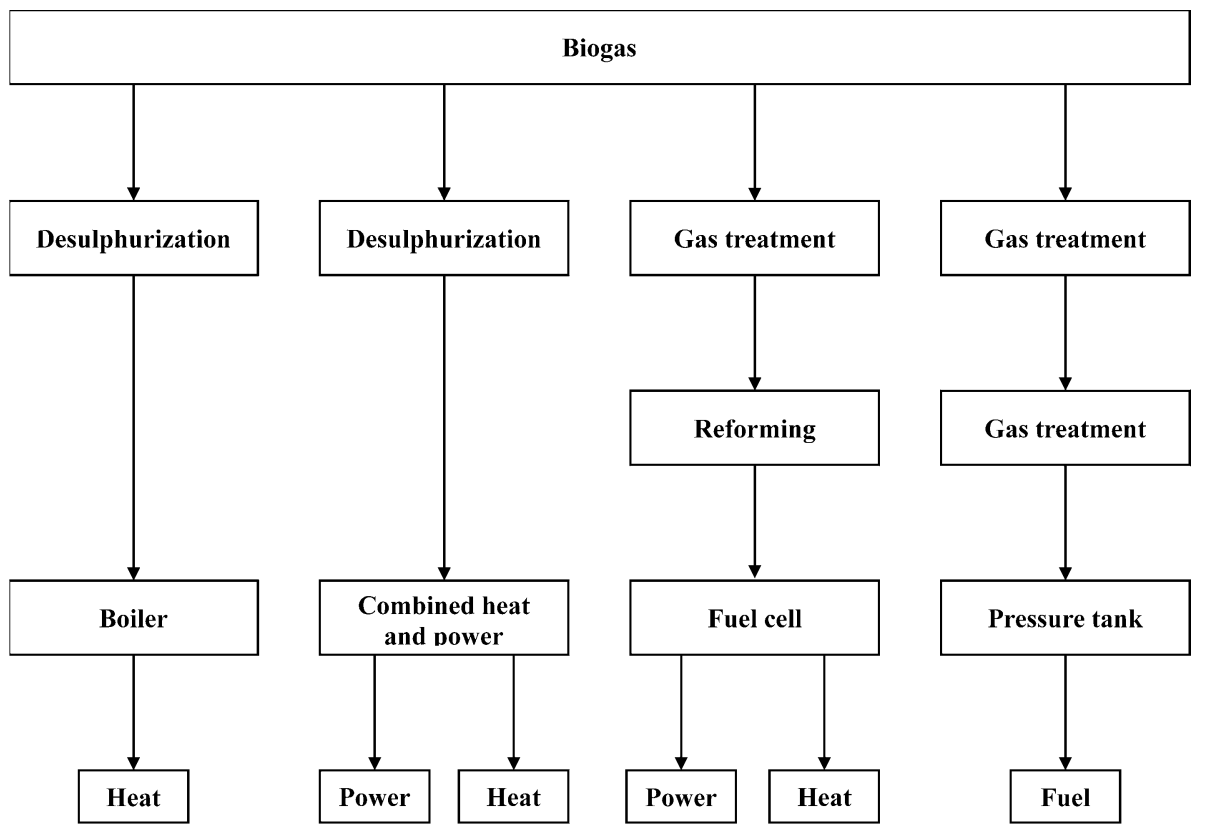

environmental and resource-efficiency viewpoint, biogas serves several benefits compared to other vehicle fuels based on biomass. This means the economic competitiveness of biogas as a vehicle fuel is elevated which motivates scientists and researchers to proceed with technological development targeted at lowering the cost (Dahlgren 2020). It has been observed in the past few years that there is an increasing interest in liquefying biogas for its utilization in heavier vehicles.

A study was conducted to provide an overview of the vehicle fuels produced from biogas and their technological advancement with the potential to serve as a transport fuel. The only commercially produced fuel using biogas is compressed and liquefied methane which lacks advantages such as the possibility of fuel cell vehicles being emissionfree compared to other fuels. Then again, the technological maturity of these other fuels is less than the compressed and liquefied methane. Therefore, increased utilization of biogas as compressed and liquefied biomethane provides the greatest short-term perspective as an alternative fuel (Prussi et al. 2021).

\section{Injecting into the natural gas grids}

In recent years, low-grade natural gas resources have been a key reason behind biogas utilization becoming the substitute for natural gas and it has gained great importance for this reason (Zheng et al. 2020). To reach the normal standard of natural gas, biomethane needs to be introduced into the natural gas grids to improve its quality. There has also been a request by the European Commission to create standards for setting a minimum acceptable range for gas quality parameters. Some European countries like Sweden, Germany, Switzerland, and France have set their own levels for biogas injection into the natural gas grids to avoid any equipment damage.

The present biogas upgrading techniques can be utilized to maintain these set standards (Nguyen et al. 2020). In a Danish investigation, biogas injection into the gas grid system for raw and improved/upgraded biogas was evaluated using the Wobbe index (WI) (Aryal and Kvist 2018). The Wobbe index is an indication of the heating capacity of a gas mixture and reviews the standard of natural gas and the potential interchange capacity of different gases. It was detected that raw biogas needs to increase the WI from 28.3 $\mathrm{MJ}$ per $\mathrm{m}^{3}$ to at least 50.76 $\mathrm{MJ}$ per $\mathrm{m}^{3}$ through upgrading. In addition to that gas consumers also studied the yearly consumption of gas to determine an alternative biogas utilization approach to cut the expenditures related to upgrading and compressing for gas grid injection.

\section{Engines and gas turbines fuel for electricity production}

Compared to natural gas, biogas has high resistance with a high compression rate and can be used as fuel in combustion motor engines that generate electricity by converting mechanical energy. In the southern region of Ecuador, a study was conducted to assess the capacity of biogas production from landfill waste to feed a power plant. The biogas production to supply electricity plants was estimated through a local mathematical model. This form of renewable energy is often of interest as electricity production is possible from 
waste materials. However, it is not an appealing option until its large-scale implementation is encouraged through the investment of taxpayer or private resources (BarragánEscandón et al. 2020). Therefore, to compete with existing technologies, these technologies require a boost to gain a foothold in the commercial marketplace.

The combined method of producing heat and electricity from biogas is considered to play a crucial role in the process of energy utilization, in addition to reducing pollution in wastewater treatment (Ahmed et al. 2021). A study was performed to generate electricity using biogas as the major source of fuel from the sewage treatment plant situated in a city in Taiwan. The results of this study show that the generator demonstrated a higher performance with increased power load. The mean adjusted concentrations of NOx and CO (approximately $15 \mathrm{vol} \% \mathrm{O}_{2}$ ) released from the generator at a power load of $30 \mathrm{~kW}$ were $17 \mathrm{ppmv}$ and $86 \mathrm{ppmv}$ each, respectively. These released gases were significantly less than the emission level of the stationary sources set for Taiwan, which corresponds to $150 \mathrm{ppmv}$ and 2,000 ppmv, respectively. The research, therefore, proved that utilizing biogas for small gas turbine power generators did not only demonstrate promising results but also performed very well in reducing greenhouse gas emissions, leading towards an environmentally and economic friendly concept (Chang et al. 2019). Biogas is a renewable and environmentally friendly fuel. It is possible to use biogas for a variety of purposes. The three primary end uses for biogas are the production of heat and steam, the generation of electricity, and the use of vehicle fuel.
The characterization of biogas according to its sources and the impact of the presence of impurities on biogas utilization are given in Table 4. As shown in Table 4, the major differences between natural gas and biogas lie in the $\mathrm{CO}_{2}$ content, which is higher in biogas, and thus reduces its calorific value compared with natural gas.

\section{Challenges of biogas upgrading technologies}

As discussed, biogas upgrading technologies utilize a variety of physical, chemical, and biological technologies. Unfortunately, all these different technologies still present several challenges that are a barrier to their adoption. Several recent articles highlight the challenges of the existing biogas upgrading technologies along with the directions for future research, namely for technologies like amine scrubbing, water scrubbing, pressure swing adsorption, membrane process, and cryogenic separation. In this paper, such challenges have been categorized under three major segments that include economic impact, environmental sustainability, and technological limitations. Though different stakeholders associated with multiple sectors using biogas upgrading technologies are trying to improve their corresponding technologies, the three above-mentioned challenge categories are more or less prevalent in almost all application areas. To assure the long-term sustainability of biogas generation and utilization, all these challenges should be properly analysed and contextualized within local and national contexts.

Table 4 Biogas composition from various sources and the impact of impurities on biogas utilization (Sun et al., 2015; Awe et al., 2017; Ullah Khan et al., 2017; Vilardi et al., 2020)

\begin{tabular}{|c|c|c|c|c|}
\hline Biogas contaminants & $\begin{array}{l}\text { Biogas } \\
\text { from } \\
\text { landfill }\end{array}$ & $\begin{array}{l}\text { Biogas from } \\
\text { anaerobic } \\
\text { digestion }\end{array}$ & Natural gas & Operational risks and effect on biogas utilization \\
\hline Lower value in heating $\left(\mathrm{MJ} / \mathrm{Nm}^{3}\right)$ & 23 & 16 & 39 & - \\
\hline $\mathrm{CH}_{4}(\%)$ & $60-70$ & $35-65$ & $85-92$ & - \\
\hline $\mathrm{CO}_{2}(\%)$ & $30-40$ & $15-40$ & $0.2-1.5$ & $\begin{array}{l}\text { Decrease calorific value and anti-knock characteristics of engines, } \\
\text { and cause corrosion }\end{array}$ \\
\hline $\mathrm{H}_{2} \mathrm{O}(\%)$ & $1-5$ & $1-5$ & n.a & $\begin{array}{l}\text { Corrosion in engines, tanks of gas storage, and compressors due } \\
\text { to the reaction with } \mathrm{CO}_{2}, \mathrm{H}_{2} \mathrm{~S}, \mathrm{NH}_{3} \text { to generate acids, and dam- } \\
\text { age by promoting the creation of condensate and ice }\end{array}$ \\
\hline $\mathrm{N}_{2}(\%)$ & 0.2 & 15 & 0.3 & Decrease calorific value and anti-knock characteristics of engines \\
\hline $\mathrm{O}_{2}(\%)$ & 0 & 1 & n.a & Corrosion and may increase incidences of explosion \\
\hline $\mathrm{H}_{2}(\%)$ & 0 & $0-3$ & n.a & - \\
\hline Heavy hydrocarbons (\%) & 0 & 0 & 9 & - \\
\hline $\mathrm{H}_{2} \mathrm{~S}(\mathrm{ppm})$ & $0-4000$ & $0-100$ & $1.1-5.9$ & $\begin{array}{l}\text { Corrosion, catalytic converter poison, emissions and may lead to } \\
\text { adverse health effects }\end{array}$ \\
\hline $\mathrm{NH}_{3}(\mathrm{ppm})$ & 100 & 5 & n.a & $\begin{array}{l}\text { Emissions, affect the anti-knock properties of engines, and cor- } \\
\text { rosion }\end{array}$ \\
\hline Total $\mathrm{Cl}^{-}\left(\mathrm{mg} / \mathrm{Nm}^{3}\right)$ & 100 & 5 & n.a & Corrosion in engines \\
\hline
\end{tabular}

n.a. Not available 


\section{Economic challenges of biogas upgrading technologies}

Like many other emerging technologies of recent days, biogas upgrading technologies are facing significant economic challenges, mostly due to the high operating cost of biogas upgrading-related generation, operation, maintenance, and utilization. Kapoor et al. (2019) argue that loss of useful chemicals from biogas plants is one of the major contributors to the economic loss of plants, and sometimes the lower generation capacity of plants also increases the per-unit operating cost of biogas. Here, the loss of useful chemicals also arises from misuse of consumed energy for biogas generation, leading to economic loss. Though these economic challenges are common in almost all the biogas upgrading plants, ex situ biogas upgrading technologies have been found to be more economically inefficient compared to the in situ biogas upgrading technologies, since ex situ settings often require significant expenditure in the creation and maintenance of a suitable environment. Despite offering a more controlled environment in the case of ex situ biogas upgrading technologies, economic inefficiency often leads to the exclusion of such approaches in different contexts (Kapoor et al. 2019).

There are several techno-economic and energy-economic challenges associated with biogas upgrading technologies that often lead to the adoption of less expensive but more energy-intensive technologies, threatening its future sustainability and relevance to the corresponding context. Unfortunately, many such technologies might be economically viable, but quite unsustainable and inappropriate (Awe et al. 2017). For instance, the adoption of highly effective biogas upgrading methodology, cryogenic technology, is often disregarded due to the high associated cost, and in such cases, inexpensive technologies are adopted (Baena-Moreno et al. 2020). In many cases, unsustainable and less appropriate biogas upgrading technologies are promoted, due to the upfront cost efficiency of the plant installation, which causes unprecedented and highly detrimental outcomes in the longer term.

However, the economic challenges associated with biogas upgrading technologies are not only limited to the above-mentioned contexts. The installation of small-scale biogas generation plants is often discouraged due to the high maintenance costs associated with small-scale plants. Especially in developing countries, decentralized smallscale biogas plants are uncommon due to the comparatively higher costs due to limitations of low-cost local resources and knowledge gaps (Chen and Liu 2017). Besides, in many of these countries, subsidization and government-initiated biogas upgradation and promotion programmes are still quite uncommon. This means stakeholders cannot be part of biogas upgradation initiatives; thus, they either switch to other unsustainable energy schemes or are forced to utilize biogas without upgradation initiatives. Economic barriers to biogas upgrading vary from one method to another. For instance, Toledo-Cervantes et al. (2017a) report that the cost efficiency of the two biogas upgrading technologies, the algal-bacterial photobioreactor and the activated carbon filter coupled with a water scrubber, and the significant variance in their land requirements, investment cost, and environmental impacts, as a whole, lead to a variation in cost. Economic challenges lag the upgradation of biogas technologies in different contexts.

\section{Challenges related to the assurance of environmental sustainability}

Biogas is one of the most sustainable energy sources and should be modified even more to increase its environmental sustainability. Biogas upgrading to biomethane is aimed at more sophisticated utilization of biogas for which the hybrid technology is required. Usually, the comparatively inexpensive biogas technologies are more environmentally unsustainable, since the environmental protection measures used in these technologies have been found to be less in number and quality. However, due to the environmental hazards that these technologies may cause, an intense cost-benefit analysis often determines the economic infeasibility of such technologies for a longer period.

In the case of biogas upgrading technologies, assurance of environmental sustainability is often determined by several variables, i.e. resource consumption, type of emission, corresponding hazards, and so on. These variables are associated with different processes in multiple ways. For example, membrane-based technologies for biogas upgradation, a physical method, is quite environmentally friendly since no harmful chemical agents are used, making the process nonhazardous; however, its efficiency is still quite poor (BaenaMoreno et al. 2020). Activated carbon filter-based biogas upgrading technologies often consume a huge amount of energy and water. At the same time, it has been found to release greenhouse gases (GHGs) (Toledo-Cervantes et al. 2017a).

GHG reduction by a greater amount through biogas upgrading is still a challenging task. However, only $10 \%$ less GHGs than the reference value can be emitted by the PSA technology in the agriculture context (Pertl et al. 2010). The specific emissions of GHG associated with biomethane generation from energy crops are found as low as $44.6 \mathrm{~g}$ $\mathrm{CO}_{2} \mathrm{eq} / \mathrm{kWh}$, implying an overall reduction of $82 \%$ in GHG emissions when compared to natural gas (Adelt et al. 2011). Nevertheless, biogas upgrading to biomethane using chemical absorption technology with potassium hydroxide aqueous solution has a lower environmental effect than that with 
mono-ethanolamine and sodium hydroxide aqueous solution (Leonzio 2016).

The examples discussed above can be considered when comparing the effectiveness of two leading physical and chemical methods for biogas upgrading in terms of their environmental sustainability. In this case, it has been observed that the comparatively more environment-friendly method is less effective, while the chemical method, despite having a satisfactory level of effectiveness, is environmentally unsustainable. The respective potential for environmental sustainability of different biogas upgrading technologies is still in question. However, to reduce environmental pollution caused by carbon-based fossil fuels, bio-CNG can play a critical role as it can be produced as a vehicle fuel from biogas (Khan et al. 2017).

\section{Technological limitations to upgrade biogas technologies}

Process optimization of biogas upgrading technologies is urgently required to ensure the long-term sustainability of biogas utilization. Different biogas upgrading technologies are still facing significant technological limitations, i.e. excessive resource consumption, the association of hazardous chemicals, inefficient strategies, and so on. These technological limitations vary between different methodologies. For example, water scrubbing, a physical method for biogas upgradation, has been found to be technologically simple but limited because in this process, a significant amount of methane is lost due to water adsorption, resulting in a significantly low yield (Cozma et al. 2013). This is also the case for other physical adsorption-based methodologies for biogas upgradation. In such cases, methane adsorption varies mostly depending on the type of solvent or adsorbents used (Ma et al. 2018).

Chemical scrubbing technology often consumes a significant amount of energy due to its inherent design requirements. Besides, many of the agents used during chemical scrubbing are carcinogenic and hazardous for both human and environmental health (Wang et al. 2019). More and more innovations are needed here so that harmful chemical agents can be replaced by non-hazardous ones. Considering the availability of the resources at different geographic locations, the upgrading processes should be adopted. Apart from that low efficiency is a technological challenge that many of the biogas upgrading technologies are still facing.

The physical methods for biogas upgradation are facing the most significant challenges. For instance, since membrane-based technologies isolate biomethane based on the size of the biogas molecules, a good number of contaminants also pass through the membrane, reducing the purity of the upgraded biogas (Baena-Moreno et al. 2020). Even in cases where the isolated biogas is of high purity, other technological barriers are present. For example, Yousef et al. (2016) reported that upgrading biogas by low-temperature $\mathrm{CO}_{2}$ removal technique offers the high purity of the biogas. However, this process itself is quite difficult to implement at a large scale due to the difficulties associated with temperature maintenance and the lack of large-scale technological settings. This process does not incorporate methane, one of the most important constituents of the biogas isolation strategy. The challenges and benefits of existing biogas upgrading technologies are given in Table 5. These challenges should be overcome to assure more effective implementation of biogas upgrading technologies.

\section{Perspectives}

There is significant scope to work on biogas upgrading technologies since this is still an emerging field that requires many improvements. All the above-mentioned challenges should be overcome through future research and innovations. To overcome the economic challenges associated with biogas upgrading technologies, cost reduction in the technology is needed. Future research should work on reducing both the investment and operating cost of the technologies so that the stakeholders can adopt the technologies at a lower cost. At the same time, efficiency should be enhanced. As noted earlier, many of the less expensive technologies for biogas upgradation are quite inefficient. Therefore, increasing the efficiency and efficacy at a lower cost is highly recommended for future research. Research should also focus on impurity removal from the isolated substances. Technologies should be designed in such a way that the impurities and the contaminants present in the isolated gaseous substance can be easily removed. In this regard, suitable adsorbents should be designed so that they do not reduce the yield of the process. The harmful chemical agents should also be replaced by less harmful and non-hazardous chemicals. The sustainability of the processes also needs to be assured through future research and innovations.

\section{Conclusion}

Biogas as a renewable energy source has increasingly proved to be a promising solution to environmental and energy issues in the world, where the application of biogas beyond heat and power generation has been expanding in recent years. This paper critically reviewed the state-of-the-art biogas upgrading technologies and the required characteristics of biogas for various utilization purposes. The existing technologies that are mature and have reached near-optimum technical and economic feasibility, and thus noticeable in wide-scale applications, are primarily physical and chemical 
Table 5 Challenges and benefits of actual biogas upgrading technologies

\begin{tabular}{|c|c|c|}
\hline Technology & Challenges & Benefits \\
\hline Vater scrubbing & $\begin{array}{l}\text { High investment and operating costs } \\
\text { Slow and less efficient process } \\
\text { High pressure is needed for compressing biogas and } \\
\text { high energy need for water circulation } \\
\text { Congestion due to bacterial growth } \\
\text { High requirement for water despite regeneration } \\
\text { Probable foaming and subsequent } \mathrm{H}_{2} \mathrm{~S} \text { poisoning lead- } \\
\text { ing to corrosion } \\
\text { Less flexibility towards variations of input gas } \\
\text { Additional drying step for removing water from biom- } \\
\text { ethane }\end{array}$ & $\begin{array}{l}\text { High efficiency: around } 97 \% \mathrm{CH}_{4} \text { recovery } \\
\text { Both } \mathrm{CO}_{2} \text { and } \mathrm{H}_{2} \mathrm{~S} \text { can be removed at once, suitable for } \\
\mathrm{H}_{2} \mathrm{~S} \text { concentration less than } 300 \mathrm{~cm}^{3} / \mathrm{m}^{3} \\
\text { Capacity is modifiable upon alterations of temperature } \\
\text { and pressure } \\
\text { Less than } 2 \% \mathrm{CH}_{4} \text { losses } \\
\text { Not overly sensitive to impurities } \\
\text { Water is a regeneration of water with ease } \\
\text { No sophisticated system or chemical requirements } \\
\text { Rapidly scalable }\end{array}$ \\
\hline Organic scrubbing & $\begin{array}{l}\text { Complex process with expensive investment and opera- } \\
\text { tion } \\
\text { Expensive for small-scale operation } \\
\text { High energy needs for solvent regeneration } \\
\text { Expensive solvent with difficult handling requirements } \\
\text { Loss of operational efficiency due to dilution of glycol } \\
\text { into } \mathrm{H}_{2} \mathrm{O} \\
\text { Difficult regeneration of solvent if } \mathrm{H}_{2} \mathrm{~S} \text { is not pre- } \\
\text { separated } \\
\text { Heating required for complete regeneration }\end{array}$ & $\begin{array}{l}\text { High } \mathrm{CH}_{4} \text { recovery efficiency }\left(>97 \% \mathrm{CH}_{4} \text { ) }\right. \\
\text { Less volume of solvent required due to high solubility of } \\
\mathrm{CO}_{2} \\
\text { Concurrent separation of contaminants including } \mathrm{H}_{2} \mathrm{~S} \\
\text { More efficient than water scrubbing } \\
\text { Low } \mathrm{CH}_{4} \text { losses } \\
\text { Recovery of residual methane is possible by heating }\end{array}$ \\
\hline Pressure swing adsorption & $\begin{array}{l}\text { Expensive investment and operation } \\
\text { Prior elimination of } \mathrm{H}_{2} \mathrm{~S} \text { and moisture is preferable } \\
\text { Off-gas from the process needs further treatment } \\
\text { Susceptible to fouling by impurities } \\
\text { High } \mathrm{CH}_{4} \text { loss if valves malfunction } \\
\text { Complicated process control }\end{array}$ & $\begin{array}{l}\text { Highly efficient } \mathrm{CH}_{4} \text { recovery }\left(96-98 \% \mathrm{CH}_{4}\right), \mathrm{H}_{2} \mathrm{~S} \text { is } \\
\text { removed } \\
\mathrm{N}_{2}, \mathrm{O}_{2} \text {, and moisture removal are possible } \\
\text { High pressure but regenerative } \\
\text { Faster installation and relatively easier operation due to } \\
\text { compact setup } \\
\text { Suitable for small capacities as well } \\
\text { Tolerant to impurities } \\
\text { Clean and water-free biomethane produced } \\
\text { Less energy requirement } \\
\text { Fast adsorbent regeneration }\end{array}$ \\
\hline Cryogenic separation & $\begin{array}{l}\text { Expensive investment, maintenance, and operation } \\
\text { High energy requirements } \\
\text { Use of various expensive process equipment } \\
\text { Contaminant pre-treatment and removal required } \\
\text { Technically complex procedure }\end{array}$ & $\begin{array}{l}\text { Up to } 98 \% \text { high-purity } \mathrm{CH}_{4} \text { recovery } \\
\text { High-purity } \mathrm{CO}_{2} \text { recovery as a by-product which can be } \\
\text { used for example as dry ice } \\
\text { Minimal additional energy is required to reach liquid } \\
\text { biomethane (LBM) production level } \\
\text { Very low } \mathrm{CH}_{4} \text { loss } \\
\text { Eco-friendly, no chemical usage is involved }\end{array}$ \\
\hline Membrane separation & $\begin{array}{l}\text { Pre-removal of } \mathrm{H}_{2} \mathrm{~S} \text { and } \mathrm{H}_{2} \mathrm{O} \text { is strongly recommended } \\
\text { Trade-off between the purity of } \mathrm{CH}_{4} \text { and quantity of } \\
\text { biomethane due to limited selectivity of membranes } \\
\text { Not appropriate for high-purity requirements } \\
\text { Low } \mathrm{CH}_{4} \text { yield from a single step } \\
\text { Multiple modules are required for high purity } \\
\text { High electricity requirement for producing each unit of } \\
\text { biomethane } \\
\text { Moderate-to-high } \mathrm{CH}_{4} \text { losses } \\
\text { Possible congestion and contamination of membranes } \\
\text { Membranes need to be replaced within } 1-5 \text { years }\end{array}$ & $\begin{array}{l}\text { Cheap investment and operation } \\
\text { Both } \mathrm{H}_{2} \mathrm{~S} \text { and } \mathrm{H}_{2} \mathrm{O} \text { are separated } \\
\text { Simple compact design, installation, and operation } \\
\text { Easy maintenance without any chemical requirements } \\
\text { Low energy requirement } \\
\text { High reliability } \\
\text { Suitable for low gas flow rates too, no substantial increase } \\
\text { in costings for small units } \\
\mathrm{CH}_{4} \text { recovery efficiency of the single-pass module is } \\
\text { around } 92 \% \mathrm{CH}_{4} \text {, for multistage units } \mathrm{CH} 4 \text { purity } \\
\text { reaches more than } 96 \% \mathrm{CH}_{4} \\
\text { Overall, environment-friendly process operation }\end{array}$ \\
\hline
\end{tabular}


Table 5 (continued)

\begin{tabular}{|c|c|c|}
\hline Technology & Challenges & Benefits \\
\hline Chemical scrubbing & $\begin{array}{l}\text { High investment cost } \\
\text { Heating is necessary for solvent regeneration } \\
\text { High energy requirement } \\
\text { Possibility of contaminant accumulation } \\
\text { Possible reaction between } \mathrm{O}_{2} \text { and amines, subsequent } \\
\text { breakdown and fouling of the amines } \\
\text { Risk of brackish coagulation and foaming } \\
\text { Corrosion potential } \\
\text { Waste chemicals require additional treatment }\end{array}$ & $\begin{array}{l}\text { High-efficiency } \mathrm{CH}_{4} \text { recovery }\left(>99 \% \mathrm{CH}_{4}\right) \\
\text { Complete } \mathrm{H}_{2} \mathrm{~S} \text { removal is possible } \\
\text { Compression of raw biogas is not mandatory } \\
\text { Can operate at low-pressure conditions } \\
\text { Low operational cost } \\
\text { Easier regeneration of the solvent } \\
\text { Larger volume of } \mathrm{CO}_{2} \text { can be dissolved in each unit of } \\
\text { chemical solvent per unit of volume compared to } \mathrm{H}_{2} \mathrm{O} \text { or } \\
\text { organic solvents } \\
\text { High selectivity for } \mathrm{CO}_{2} \text { with minimal } \mathrm{CH}_{4} \text { losses, less } \\
\text { than } 0.1 \%\end{array}$ \\
\hline Biological upgrading & $\begin{array}{l}\text { Still in pilot scale, no reliable data on investment, opera- } \\
\text { tion, and maintenance cost } \\
\text { Limitations and challenges for larger-scale operation is } \\
\text { still unknown } \\
\text { Huge need for large amounts of } \mathrm{H}_{2} \\
\text { Risk of fire and explosion if the setups are not handled } \\
\text { properly } \\
\text { Operational parameters, mainly pH should be regularly } \\
\text { monitored and controlled }\end{array}$ & $\begin{array}{l}\text { Isolation of both } \mathrm{H}_{2} \mathrm{~S} \text { and } \mathrm{CO}_{2} \text { are possible } \\
\text { Enrichment of biomethane } \\
\text { Generation of valuable by-products in some cases } \\
\text { Environment friendly } \\
\text { No chemical requirements } \\
\text { Minimal or no heating required } \\
\text { No undesirable by-product or end-product development }\end{array}$ \\
\hline
\end{tabular}

biogas upgrading technologies. However, such technologies consume huge amounts of energy and resources, which significantly hinder the expansion of the biogas market as a promising renewable energy source. The selection of appropriate technologies may depend on various factors other than costs, such as biogas quality, location, and technology requirements.

Less explored are the biological methods in industrialscale testing and optimization scenarios, despite showing huge potential in terms of techno-economic feasibility and the opening of new horizons in hybrid renewable energy systems. Large gaps are also present in the pilot scale and commercial scale applications of novel technologies like hydrate separation, biotechnologies, cryogenic separation, and chemolithotrophic-based bioreactors. Cost remains a major limitation to widespread biogas application. Therefore, research and development in increasing optimization of biogas upgrading and utilization using techno-economically feasible and environmentally friendly technologies need to be encouraged using subsidies, grants, and other forms of incentives and government support to tackle the world's energy security, waste management, and climate changerelated challenges.

\section{References}

Abou Rjeily M, Gennequin C, Pron H, Abi-Aad E, Randrianalisoa JH (2021) Pyrolysis-catalytic upgrading of bio-oil and pyrolysiscatalytic steam reforming of biogas: a review. Environl Chem Lett 19(4):2825-2872
Adelt M, Wolf D, Vogel A (2011) LCA of biomethane. J Nat Gas Sci Eng 3:646-650. https://doi.org/10.1016/j.jngse.2011.07.003

Adnan AI, Ong MY, Nomanbhay S, Chew KW, Show PL (2019) Technologies for biogas upgrading to biomethane: a review. Bioengineering 6:92. https://doi.org/10.3390/bioengineering6040092

Agbroko OW, Piler K, Benson TJ (2017) A comprehensive review of $\mathrm{H} 2 \mathrm{~S}$ scavenger technologies from oil and gas streams. ChemBioEng Rev 4:339-359. https://doi.org/10.1002/cben.201600026

Agneessens LM, Ottosen LDM, Voigt NV, Nielsen JL, de Jonge N, Fischer CH, Kofoed MVW (2017) In-situ biogas upgrading with pulse $\mathrm{H}(2)$ additions: the relevance of methanogen adaption and inorganic carbon level. Bioresour Technol 233:256263. https://doi.org/10.1016/j.biortech.2017.02.016

Ahmed SF, Khan MMK, Amanullah M, Rasul M, Hassan N (2013) Thermal performance analysis of earth pipe cooling system for subtropical climate. 12th International conference on sustainable energy technologies, Hong Kong. pp 1795-1803.

Ahmed SF, Khan MMK, Amanullah M, Rasul M, Hassan N (2014) Performance analysis of vertical earth pipe cooling system for subtropical climate. 13th International conference on clean energy. pp 691-700. https://doi.org/10.13140/2.1.1730.9764

Ahmed SF, Mofijur M, Nuzhat S, Chowdhury AT, Rafa N, Uddin MA, Inayat A, Mahlia T, Ong HC, Chia WY (2021) Recent developments in physical, biological, chemical, and hybrid treatment techniques for removing emerging contaminants from wastewater. J Hazard Mater 416:125912

Alami AH, Alasad S, Ali M, Alshamsi M (2021) Investigating algae for $\mathrm{CO} 2$ capture and accumulation and simultaneous production of biomass for biodiesel production. Sci Total Environ 759:143529. https://doi.org/10.1016/j.scitotenv.2020.143529

Alcántara C, García-Encina PA, Muñoz R (2013) Evaluation of mass and energy balances in the integrated microalgae growthanaerobic digestion process. Chem Eng J 221:238-246. https:// doi.org/10.1016/j.cej.2013.01.100

Alitalo A, Niskanen M, Aura E (2015) Biocatalytic methanation of hydrogen and carbon dioxide in a fixed bed bioreactor. Bioresour Technol 196:600-605. https://doi.org/10.1016/j.biortech. 2015.08.021 
Allegue LB, Hinge J, Allé K (2012) Biogas and bio-syngas upgrading. Danish Technological Institute. pp 5-97.

Al-Mamoori A, Krishnamurthy A, Rownaghi AA, Rezaei F (2017) Carbon capture and utilization update. Energy Technol 5:834849. https://doi.org/10.1002/ente.201600747

Andriani D, Rajani A, Santosa A, Saepudin A, Wresta A, Atmaja T (2020) A review on biogas purification through hydrogen sulphide removal. IOP Conf Ser Earth Environ Sci 483:012034. https://doi.org/10.1088/1755-1315/483/1/012034

Andriani D, Wresta A, Atmaja TD, Saepudin A (2014) A review on optimization production and upgrading biogas through $\mathrm{CO} 2$ removal using various techniques. Appl Biochem Biotechnol 172:1909-1928. https://doi.org/10.1007/s12010-013-0652-x

Angelidaki I, Treu L, Tsapekos P, Luo G, Campanaro S, Wenzel H, Kougias PG (2018) Biogas upgrading and utilization: current status and perspectives. Biotechnol Adv 36:452-466. https://doi. org/10.1016/j.biotechadv.2018.01.011

Aryal N, Kvist T (2018) Alternative of biogas injection into the Danish gas grid system-A study from demand perspective. ChemEng 2:43. https://doi.org/10.3390/chemengineering2030043

Augelletti R, Conti M, Annesini MC (2017) Pressure swing adsorption for biogas upgrading. A new process configuration for the separation of biomethane and carbon dioxide. J Clean Prod 140:1390-1398. https://doi.org/10.1016/j.jclepro.2016.10.013

Awasthi MK, Sarsaiya S, Patel A, Juneja A, Singh RP, Yan B, Awasthi SK, Jain A, Liu T, Duan Y (2020) Refining biomass residues for sustainable energy and bio-products: an assessment of technology, its importance, and strategic applications in circular bioeconomy. Renew Sustain Energy Rev 127:109876. https://doi. org/10.1016/j.rser.2020.109876

Awe OW, Zhao Y, Nzihou A, Minh DP, Lyczko N (2017) A review of biogas utilisation, purification and upgrading technologies. Waste Biomass Valoriz 8:267-283. https://doi.org/10.1007/ s12649-016-9826-4

Axelsson L, Franzén M, Ostwald M, Berndes G, Lakshmi G, Ravindranath N (2012) Perspective: jatropha cultivation in southern India: assessing farmers' experiences. Biofuels Bioprod BioreFining 6:246-256. https://doi.org/10.1002/bbb.1324

Baena-Moreno FM, le Saché E, Pastor-Pérez L, Reina T (2020) Membrane-based technologies for biogas upgrading: a review. Environ Chem Lett 18(5):1649-1658. https://doi.org/10.1007/ s10311-020-01036-3

Baena-Moreno FM, Rodríguez-Galán M, Vega F, Reina TR, Vilches LF, Navarrete B (2018) Regeneration of sodium hydroxide from a biogas upgrading unit through the synthesis of precipitated calcium carbonate: an experimental influence study of reaction parameters. Processes 6:205. https://doi.org/10.3390/pr6110205

Baena-Moreno FM, Rodríguez-Galán M, Reina T, Zhang Z, Vilches LF, Navarrete B (2019a) Understanding the effect of Ca and Mg ions from wastes in the solvent regeneration stage of a biogas upgrading unit. Sci Total Environ 691:93-100. https://doi.org/ 10.1016/j.scitotenv.2019.07.135

Baena-Moreno FM, Rodríguez-Galán M, Vega F, Vilches LF, Navarrete B, Zhang Z (2019b) Biogas upgrading by cryogenic techniques. Environ Chem Lett 17:1251-1261. https://doi.org/10. 1007/s10311-019-00872-2

Bahr M, Díaz I, Dominguez A, Gonzalez Sanchez A, Muñoz R (2014) Microalgal-biotechnology as a platform for an integral biogas upgrading and nutrient removal from anaerobic effluents. Environ Sci Technol 48:573-581. https://doi.org/10.1007/ s10311-019-00872-2

Barbera E, Menegon S, Banzato D, D’Alpaos C, Bertucco A (2019) From biogas to biomethane: a process simulation-based technoeconomic comparison of different upgrading technologies in the Italian context. Renewable Energy 135:663-673. https://doi.org/ 10.1016/j.renene.2018.12.052
Barragán-Escandón A, Olmedo Ruiz JM, Curillo Tigre JD, ZalameaLeón EF (2020) Assessment of power generation using biogas from landfills in an equatorial tropical context. Sustainability 12:2669. https://doi.org/10.3390/su12072669

Bassani I, Kougias PG, Treu L, Angelidaki I (2015) Biogas upgrading via hydrogenotrophic methanogenesis in two-stage continuous stirred tank reactors at mesophilic and thermophilic conditions. Environ Sci Technol 49:12585-12593. https://doi.org/10.1021/ acs.est.5b03451

Bassani I, Kougias PG, Angelidaki I (2016) In-situ biogas upgrading in thermophilic granular UASB reactor: key factors affecting the hydrogen mass transfer rate. Bioresour Technol 221:485-491. https://doi.org/10.1016/j.biortech.2016.09.083

Bassani I, Kougias PG, Treu L, Porté H, Campanaro S, Angelidaki I (2017) Optimization of hydrogen dispersion in thermophilic up-flow reactors for $e x$ situ biogas upgrading. Bioresour Technol 234:310-319. https://doi.org/10.1016/j.biortech.2017.03.055

Basso GL, de Santoli L, Paiolo R, Losi C (2021) The potential role of trans-critical $\mathrm{CO} 2$ heat pumps within a solar cooling system for building services: the hybridised system energy analysis by a dynamic simulation model. Renew Energy 164:472-490. https:// doi.org/10.1016/j.renene.2020.09.098

Bauer F, Hulteberg C, Persson T, Tamm D (2013a) Biogas upgradingreview of commercial technologies; Biogasuppgradering-Granskning av kommersiella tekniker.

Bauer F, Persson T, Hulteberg C, Tamm D (2013b) Biogas upgrading-technology overview, comparison and perspectives for the future. Biofuels, Bioprod Biorefin 7:499-511. https://doi.org/10. 1002/bbb. 1423

Bekkering J, Broekhuis AA, van Gemert WJ (2010) Optimisation of a green gas supply chain-a review. Bioresour Technol 101:450456. https://doi.org/10.1016/j.biortech.2009.08.106

Benizri D, Dietrich N, Labeyrie P, Hébrard G (2019) A compact, economic scrubber to improve farm biogas upgrading systems. Sep Purif Technol 219:169-179. https://doi.org/10.1016/j.seppur. 2019.02.054

Berlemann M, Steinhardt MF (2017) Climate change, natural disasters, and migration-a survey of the empirical evidence. Cesifo Econ Stud 63:353-385. https://doi.org/10.1093/cesifo/ifx019

Bharathiraja B, Sudharsana T, Jayamuthunagai J, Praveenkumar R, Chozhavendhan S, Iyyappan J (2018) Biogas production-a review on composition, fuel properties, feed stock and principles of anaerobic digestion. Renew Sustain Energy Rev 90:570-582. https://doi.org/10.1016/j.rser.2018.03.093

Bose A, Lin R, Rajendran K, O'Shea R, Xia A, Murphy JD (2019) How to optimise photosynthetic biogas upgrading: a perspective on system design and microalgae selection. Biotechnol Adv 37:107444. https://doi.org/10.1016/j.biotechadv.2019.107444

Burkhardt M, Koschack T, Busch G (2015) Biocatalytic methanation of hydrogen and carbon dioxide in an anaerobic three-phase system. Biores Technol 178:330-333. https://doi.org/10.1016/j.biortech. 2014.08.023

Canevesi RL, Andreassen KA, da Silva EA, Borba CE, Grande CA (2018) Pressure swing adsorption for biogas upgrading with carbon molecular sieve. Ind Eng Chem Res 57:8057-8067. https:// doi.org/10.1021/acs.iecr.8b00996

Casado-Coterillo C, Garea A, Irabien Á (2020) Effect of water and organic pollutant in $\mathrm{CO} 2 / \mathrm{CH} 4$ separation using hydrophilic and hydrophobic composite membranes. Membranes 10:405. https:// doi.org/10.3390/membranes10120405

Chaemchuen S, Zhou K, Verpoort F (2016) From biogas to biofuel: materials used for biogas cleaning to biomethane. ChemBioEng Rev 3:250-265. https://doi.org/10.1002/cben.201600016

Chang C-C, Do MV, Hsu W-L, Liu B-L, Chang C-Y, Chen Y-H, Yuan M-H, Lin C-F, Yu C-P, Chen Y-H (2019) A case study on the electricity generation using a micro gas turbine fuelled by biogas 
from a sewage treatment plant. Energies 12:2424. https://doi.org/ $10.3390 /$ en 12122424

Chang H, Zou Y, Hu R, Feng H, Wu H, Zhong N, Hu J (2020) Membrane applications for microbial energy conversion: a review. Environ Chem Lett 18(5):1581-1592. https://doi.org/10.1007/ s10311-020-01032-7

Chen Q, Liu T (2017) Biogas system in rural China: upgrading from decentralized to centralized? Renew Sustain Energy Rev 78:933944. https://doi.org/10.1016/j.rser.2017.04.113

Chen XY, Vinh-Thang H, Ramirez AA, Rodrigue D, Kaliaguine S (2015) Membrane gas separation technologies for biogas upgrading. RSC Adv 5:24399-24448. https://doi.org/10.1039/C5RA0 0666 J

Cheng Y, Ying Y, Zhai L, Liu G, Dong J, Wang Y, Christopher MP, Long S, Wang Y, Zhao D (2019) Mixed matrix membranes containing MOF@ COF hybrid fillers for efficient $\mathrm{CO} 2 / \mathrm{CH} 4$ separation. J Membr Sci 573:97-106. https://doi.org/10.1016/j.memsci. 2018.11.060

Chew KR, Leong HY, Khoo KS, Vo D-VN, Anjum H, Chang C-K, Show PL (2021) Effects of anaerobic digestion of food waste on biogas production and environmental impacts: a review. Environ Chem Lett 19(4):2921-2939. https://doi.org/10.1007/ s10311-021-01220-z

Cozma P, Ghinea C, Mămăligă I, Wukovits W, Friedl A, Gavrilescu M (2013) Environmental impact assessment of high pressure water scrubbing biogas upgrading technology. CLEAN-Soil Air, Water 41:917-927. https://doi.org/10.1002/clen.201200303

Dahlgren S (2020) Biogas-based fuels as renewable energy in the transport sector: an overview of the potential of using CBG, LBG and other vehicle fuels produced from biogas. Biofuels. https://doi. org/10.1080/17597269.2020.1821571

De Godos I, Mendoza J, Acién F, Molina E, Banks C, Heaven S, Rogalla F (2014) Evaluation of carbon dioxide mass transfer in raceway reactors for microalgae culture using flue gases. Biores Technol 153:307-314. https://doi.org/10.1016/j.biortech.2013. 11.087

De Guido G, Compagnoni M, Pellegrini LA, Rossetti I (2018) Mature versus emerging technologies for $\mathrm{CO} 2$ capture in power plants: key open issues in post-combustion amine scrubbing and in chemical looping combustion. Front Chem Sci Eng 12:315-325. https://doi.org/10.1007/s11705-017-1698-z

Deviram G, Mathimani T, Anto S, Ahamed TS, Ananth DA, Pugazhendhi A (2020) Applications of microalgal and cyanobacterial biomass on a way to safe, cleaner and a sustainable environment. J Clean Prod 253:119770. https://doi.org/10.1016/j.jclepro.2019. 119770

Fairbrother M, Sevä IJ, Kulin J (2019) Political trust and the relationship between climate change beliefs and support for fossil fuel taxes: evidence from a survey of 23 European countries. Glob Environ Chang 59:102003. https://doi.org/10.1016/j.gloenvcha. 2019.102003

Gadikota G (2020) Multiphase carbon mineralization for the reactive separation of $\mathrm{CO}_{2}$ and directed synthesis of $\mathrm{H}_{2}$. Nat Rev Chem 4:78-89. https://doi.org/10.1038/s41570-019-0158-3

Galizia M, Chi WS, Smith ZP, Merkel TC, Baker RW, Freeman BD (2017) 50th anniversary perspective: polymers and mixed matrix membranes for gas and vapor separation: a review and prospective opportunities. Macromolecules 50:7809-7843. https://doi. org/10.1021/acs.macromol.7b01718

Grim RG, Huang Z, Guarnieri MT, Ferrell JR, Tao L, Schaidle JA (2020) Transforming the carbon economy: challenges and opportunities in the convergence of low-cost electricity and reductive $\mathrm{CO}_{2}$ utilization. Energy Environ Sci 13:472-494. https://doi.org/ 10.1039/C9EE02410G

Guneratnam AJ, Ahern E, FitzGerald JA, Jackson SA, Xia A, Dobson ADW, Murphy JD (2017) Study of the performance of a thermophilic biological methanation system. Bioresour Technol 225:308-315. https://doi.org/10.1016/j.biortech.2016.11.066.10. 1016/j.biortech.2016.11.066

Hashemi SE, Sarker S, Lien KM, Schnell SK, Austbø B (2019) Cryogenic vs. absorption biogas upgrading in liquefied biomethane production-an energy efficiency analysis. Fuel 245:294-304. https://doi.org/10.1016/j.fuel.2019.01.172

Hazrat MA, Rasul MG, Khan MMK, Mofijur M, Ahmed SF, Ong HC, Vo D-VN, Show PL (2021) Techniques to improve the stability of biodiesel: a review. Environ Chem Lett. https://doi. org/10.1007/s10311-020-01166-8

He Q, Shi M, Liang F, Xu L, Ji L, Yan S (2019) Renewable absorbents for $\mathrm{CO} 2$ capture: from biomass to nature. Greenh Gases Sci Technol 9:637-651. https://doi.org/10.1002/ghg.1902

Hidalgo D, Sanz-Bedate S, Martín-Marroquín J, Castro J, Antolín G (2020) Selective separation of $\mathrm{CH} 4$ and $\mathrm{CO} 2$ using membrane contactors. Renew Energy 150:935-942. https://doi.org/10. 1016/j.renene.2019.12.073

Hosseini SE, Wahid MA (2014) Development of biogas combustion in combined heat and power generation. Renew Sustain Energy Rev 40:868-875. https://doi.org/10.1016/j.rser.2014.07.204

Hosseinipour SA, Mehrpooya M (2019) Comparison of the biogas upgrading methods as a transportation fuel. Renew Energy 130:641-655. https://doi.org/10.1016/j.renene.2018.06.089

Hu D, Yan L, Liu T, Xu Z, Zhao L (2019) Solubility and diffusion behavior of compressed $\mathrm{CO} 2$ in polyurethane oligomer. J Appl Polym Sci 136:47100. https://doi.org/10.1002/app.47100

Hunter-Sellars E, Tee J, Parkin IP, Williams DR (2020) Adsorption of volatile organic compounds by industrial porous materials: impact of relative humidity. Microporous Mesoporous Mater 298:110090. https://doi.org/10.1016/j.micromeso.2020.110090

Jiang M, Song S, Liu H, Wang P, Dai X (2021) Effect of gentamicin mycelial residues disintegration by microwave-alkaline pretreatment on methane production and gentamicin degradation during anaerobic digestion. Chem Eng J 414:128790. https:// doi.org/10.1016/j.cej.2021.128790

Jürgensen L, Ehimen EA, Born J, Holm-Nielsen JB (2014) Utilization of surplus electricity from wind power for dynamic biogas upgrading: Northern Germany case study. Biomass Bioenergy 66:126-132. https://doi.org/10.1016/j.biombioe.2014.02.032

Kadam R, Panwar NL (2017) Recent advancement in biogas enrichment and its applications. Renew Sustain Energy Rev 73:892903. https://doi.org/10.1016/j.rser.2017.01.167

Kao C-Y, Chiu S-Y, Huang T-T, Dai L, Hsu L-K, Lin C-S (2012) Ability of a mutant strain of the microalga Chlorella sp. to capture carbon dioxide for biogas upgrading. Appl Energy 93:176-183. https://doi.org/10.1016/j.apenergy.2011.12.082

Kapoor R, Ghosh P, Kumar M, Vijay VK (2019) Evaluation of biogas upgrading technologies and future perspectives: a review. Environ Sci Pollut Res 26:11631-11661. https://doi.org/10.1007/ s11356-019-04767-1

Kapoor R, Subbarao P, Vijay VK, Shah G, Sahota S, Singh D, Verma M (2017) Factors affecting methane loss from a water scrubbing based biogas upgrading system. Appl Energy 208:13791388. https://doi.org/10.1016/j.apenergy.2017.09.017

Khan IU, Othman MHD, Hashim H, Matsuura T, Ismail A, RezaeiDashtArzhandi M, Azelee IW (2017) Biogas as a renewable energy fuel-a review of biogas upgrading, utilisation and storage. Energy Convers Manage 150:277-294. https://doi.org/10. 1016/j.enconman.2017.08.035

Kim S, Scholes CA, Heath DE, Kentish SE (2021) Gas-liquid membrane contactors for carbon dioxide separation: a review. Chem Eng J 411:128468. https://doi.org/10.1016/j.cej.2021.128468

Kiss AA, Smith R (2020) Rethinking energy use in distillation processes for a more sustainable chemical industry. Energy 203:117788. https://doi.org/10.1016/j.energy.2020.117788 
Kohlheb N, Wluka M, Bezama A, Thrän D, Aurich A, Müller RA (2020) Environmental-economic assessment of the pressure swing adsorption biogas upgrading technology. BioEnergy Res. https://doi.org/10.1007/s12155-020-10205-9

Kougias PG, Treu L, Benavente DP, Boe K, Campanaro S, Angelidaki I (2017a) Ex-situ biogas upgrading and enhancement in different reactor systems. Biores Technol 225:429-437. https:// doi.org/10.1016/j.biortech.2016.11.124

Kougias PG, Treu L, Benavente DP, Boe K, Campanaro S, Angelidaki I (2017b) Ex-situ biogas upgrading and enhancement in different reactor systems. Bioresour Technol 225:429-437. https://doi.org/10.1016/j.biortech.2016.11.124

Lask J, Martínez Guajardo A, Weik J, von Cossel M, Lewandowski I, Wagner M (2020) Comparative environmental and economic life cycle assessment of biogas production from perennial wild plant mixtures and maize (Zea mays L.) in Southwest Germany. GCB Bioenergy 12:571-585. https://doi.org/10.1111/gcbb.12715

Leonzio G (2016) Upgrading of biogas to bio-methane with chemical absorption process: simulation and environmental impact. J Clean Prod 131:364-375. https://doi.org/10.1016/j.jclepro.2016.05.020

Liemberger W, Groß M, Miltner M, Harasek M (2017) Experimental analysis of membrane and pressure swing adsorption (PSA) for the hydrogen separation from natural gas. J Clean Prod 167:896907. https://doi.org/10.1016/j.jclepro.2017.08.012

Lombardi L, Francini G (2020) Techno-economic and environmental assessment of the main biogas upgrading technologies. Renew Energy 156:440-458. https://doi.org/10.1016/j.renene.2020.04.083

Lu P, Liu Y, Zhou T, Wang Q, Li Y (2018) Recent advances in layered double hydroxides (LDHs) as two-dimensional membrane materials for gas and liquid separations. J Membr Sci 567:89-103. https://doi.org/10.1016/j.memsci.2018.09.041

Luo G, Angelidaki I (2012) Integrated biogas upgrading and hydrogen utilization in an anaerobic reactor containing enriched hydrogenotrophic methanogenic culture. Biotechnol Bioeng 109:27292736. https://doi.org/10.1002/bit.24557.10.1002/bit.24557

Luo G, Angelidaki I (2013a) Co-digestion of manure and whey for in situ biogas upgrading by the addition of $\mathrm{H}_{2}$ : process performance and microbial insights. Appl Microbiol Biotechnol 97:13731381. https://doi.org/10.1007/s00253-012-4547-5

Luo G, Angelidaki I (2013b) Hollow fiber membrane based $\mathrm{H}_{2}$ diffusion for efficient in situ biogas upgrading in an anaerobic reactor. Appl Microbiol Biotechnol 97:3739-3744. https://doi.org/10. 1007/s00253-013-4811-3.10.1007/s00253-013-4811-3

Ma C, Liu C, Lu X, Ji X (2018) Techno-economic analysis and performance comparison of aqueous deep eutectic solvent and other physical absorbents for biogas upgrading. Appl Energy 225:437447. https://doi.org/10.1016/j.apenergy.2018.04.112

Mahmudul HM, Rasul MG, Akbar D, Narayanan R, Mofijur M (2021) A comprehensive review of the recent development and challenges of a solar-assisted biodigester system. Sci Total Environ 753:141920. https://doi.org/10.1016/j.scitotenv.2020.141920

Miltner M, Makaruk A, Harasek M (2017) Review on available biogas upgrading technologies and innovations towards advanced solutions. J Clean Prod 161:1329-1337. https://doi.org/10.1016/j. jclepro.2017.06.045

Mofijur M, Fattah IR, Kumar PS, Siddiki SYA, Rahman SA, Ahmed SF, Ong HC, Lam SS, Badruddin IA, Khan TY (2021) Bioenergy recovery potential through the treatment of the meat processing industry waste in Australia. J Environ Chem Eng 9:105657. https://doi.org/10.1016/j.jece.2021.105657

Mofijur M, Mahlia TMI, Silitonga AS, Ong HC, Silakhori M, Hasan MH, Putra N, Rahman SMA (2019) Phase change materials $(\mathrm{pcm})$ for solar energy usages and storage: an overview. Energies. https://doi.org/10.3390/en12163167.10.3390/en12163167

Mofijur M, Rasul MG, Hyde J, Azad AK, Mamat R, Bhuiya MMK (2016) Role of biofuel and their binary (diesel-biodiesel) and ternary (ethanol-biodiesel-diesel) blends on internal combustion engines emission reduction. Renew Sustain Energy Rev 53:265-278. https://doi.org/10.1016/j.rser.2015.08.046

Morero B, Groppelli ES, Campanella EA (2017) Evaluation of biogas upgrading technologies using a response surface methodology for process simulation. J Clean Prod 141:978-988. https://doi. org/10.1016/j.jclepro.2016.09.167

Muhammad G, Alam MA, Mofijur M, Jahirul MI, Lv Y, Xiong W, Ong HC, Xu J (2021) Modern developmental aspects in the field of economical harvesting and biodiesel production from microalgae biomass. Renew Sustain Energy Rev 135:110209. https://doi.org/ 10.1016/j.rser.2020.110209

Mulat DG, Mosbæk F, Ward AJ, Polag D, Greule M, Keppler F, Nielsen JL, Feilberg A (2017) Exogenous addition of H(2) for an in situ biogas upgrading through biological reduction of carbon dioxide into methane. Waste Manag 68:146-156. https://doi.org/ 10.1016/j.wasman.2017.05.054

Muñoz R, Meier L, Diaz I, Jeison D (2015) A review on the stateof-the-art of physical/chemical and biological technologies for biogas upgrading. Rev Environ Sci Bio/technol 14:727-759. https://doi.org/10.1007/s11157-015-9379-1

Murdock HE, Gibb D, André T, Sawin JL, Brown A, Appavou F, Ellis G, Epp B, Guerra F, Joubert F (2020) Renewables 2020-Global status report.

Nakao S-i, Yogo K, Goto K, Kai T, Yamada H (2019) Advanced $\mathrm{CO} 2$ capture technologies: absorption, adsorption, and membrane separation methods. Springer. https://doi.org/10.1007/ 978-3-030-18858-0

Nevzorova T, Karakaya E (2020) Explaining the drivers of technological innovation systems: the case of biogas technologies in mature markets. J Clean Prod 259:120819. https://doi.org/10.1016/j.jclep ro.2020.120819

Nguyen LN, Kumar J, Vu MT, Mohammed JA, Pathak N, Commault AS, Sutherland D, Zdarta J, Tyagi VK, Nghiem LD (2020) Biomethane production from anaerobic co-digestion at wastewater treatment plants: a critical review on development and innovations in biogas upgrading techniques. Sci Total Environ 765:142753. https://doi.org/10.1016/j.scitotenv.2020.142753

Niesner J, Jecha D, Stehlík P (2013) Biogas upgrading technologies: state of art review in European region. Chem Eng Trans 35:517522. https://doi.org/10.3303/CET1335086

Nisbet E, Fisher R, Lowry D, France J, Allen G, Bakkaloglu S, Broderick T, Cain M, Coleman M, Fernandez J (2020) Methane mitigation: methods to reduce emissions, on the path to the Paris agreement. Rev Geophys. https://doi.org/10.1029/2019RG000675

Norahim N, Yaisanga P, Faungnawakij K, Charinpanitkul T, Klaysom $\mathrm{C}$ (2018) Recent membrane developments for $\mathrm{CO}_{2}$ separation and capture. Chem Eng Technol 41:211-223. https://doi.org/10. 1002/ceat.201700406

Nordberg Å, Edström M, Uusi-Penttilä M, Rasmuson ÅC (2012) Selective desorption of carbon dioxide from sewage sludge for in-situ methane enrichment: enrichment experiments in pilot scale. Biomass Bioenerg 37:196-204. https://doi.org/10.1016/j.biombioe.2011.12.012

Noroozi Z, Bakhtiari O (2019) Preparation of amino functionalized titanium oxide nanotubes and their incorporation within Pebax/ PEG blended matrix for $\mathrm{CO} 2 / \mathrm{CH} 4$ separation. Chem Eng Res Des 152:149-164. https://doi.org/10.1016/j.cherd.2019.09.030

Ochedi FO, Yu J, Yu H, Liu Y, Hussain A (2020) Carbon dioxide capture using liquid absorption methods: a review. Environ Chem Lett 19(1):77-109. https://doi.org/10.1007/s10311-020-01093-8

Ong HC, Tiong YW, Goh BHH, Gan YY, Mofijur M, Fattah IMR, Chong CT, Alam MA, Lee HV, Silitonga AS, Mahlia TMI (2020) Recent advances in biodiesel production from agricultural products and microalgae using ionic liquids: Opportunities and challenges. Energy Convers Manag 228:113647. https://doi.org/10. 1016/j.enconman.2020.113647 
Osman AI, Hefny M, Maksoud MA, Elgarahy AM, Rooney DW (2020) Recent advances in carbon capture storage and utilisation technologies: a review. Environ Chem Lett 19(2):797-849. https:// doi.org/10.1007/s10311-020-01133-3

Paolini V, Torre M, Giacopini W, Pastori M, Segreto M, Tomassetti L, Carnevale M, Gallucci F, Petracchini F, Guerriero E (2019) $\mathrm{CO} 2 / \mathrm{CH} 4$ separation by hot potassium carbonate absorption for biogas upgrading. Int J Greenh Gas Control 83:186-194. https:// doi.org/10.1016/j.ijggc.2019.02.011

Patterson T, Esteves S, Dinsdale R, Guwy A (2011) An evaluation of the policy and techno-economic factors affecting the potential for biogas upgrading for transport fuel use in the UK. Energy Policy 39:1806-1816. https://doi.org/10.1016/j.enpol.2011.01.017

Peng L, Fu D, Chu H, Wang Z, Qi H (2020) Biofuel production from microalgae: a review. Environ Chem Lett 18:285-297. https:// doi.org/10.1007/s10311-019-00939-0

Pertl A, Mostbauer P, Obersteiner G (2010) Climate balance of biogas upgrading systems. Waste Manage 30:92-99. https://doi.org/10. 1016/j.wasman.2009.08.011

Petersson A, Wellinger A (2009) Biogas upgrading technologies-developments and innovations. IEA Bioenergy 20:1-19

Préat N, Taelman SE, De Meester S, Allais F, Dewulf J (2020) Identification of microalgae biorefinery scenarios and development of mass and energy balance flowsheets. Algal Res 45:101737. https://doi.org/10.1016/j.algal.2019.101737

Prussi M, Julea A, Lonza L, Thiel C (2021) Biomethane as alternative fuel for the EU road sector: analysis of existing and planned infrastructure. Energ Strat Rev 33:100612. https://doi.org/10. 1016/j.esr.2020.100612

Qasem NA, Ben-Mansour R (2018) Energy and productivity efficient vacuum pressure swing adsorption process to separate $\mathrm{CO} 2$ from $\mathrm{CO} 2 /$ N2 mixture using Mg-MOF-74: a CFD simulation. Appl Energy 209:190-202. https://doi.org/10.1016/j.apenergy.2017.10.098

Qyyum MA, Haider J, Qadeer K, Valentina V, Khan A, Yasin M, Aslam M, De Guido G, Pellegrini LA, Lee M (2020) Biogas to liquefied biomethane: assessment of 3P's-production, processing, and prospects. Renew Sustain Energy Rev 119:109561. https://doi.org/10.1016/j.rser.2019.109561

Raboni M, Urbini G (2014) Production and use of biogas in Europe: a survey of current status and perspectives. Revista Ambiente Agua 9:191-202. https://doi.org/10.4136/ambi-agua.1324

Rachbauer L, Voitl G, Bochmann G, Fuchs W (2016) Biological biogas upgrading capacity of a hydrogenotrophic community in a trickle-bed reactor. Appl Energy 180:483-490. https://doi.org/ 10.1016/j.apenergy.2016.07.109

Rafiee A, Khalilpour KR, Prest J, Skryabin I (2021) Biogas as an energy vector. Biomass Bioenerg 144:105935. https://doi.org/ 10.1016/j.biombioe.2020.105935

Ramírez-Santos ÁA, Bozorg M, Addis B, Piccialli V, Castel C, Favre E (2018) Optimization of multistage membrane gas separation processes. Example of application to $\mathrm{CO} 2$ capture from blast furnace gas. J Membr Sci 566:346-366. https://doi.org/10.1016/j. memsci.2018.08.024

Raugei M, Peluso A, Leccisi E, Fthenakis V (2020) Life-cycle carbon emissions and energy return on investment for $80 \%$ domestic renewable electricity with battery storage in California (USA). Energies 13:3934. https://doi.org/10.3390/en13153934

Raza A, Gholami R, Rezaee R, Rasouli V, Rabiei M (2019) Significant aspects of carbon capture and storage-a review. Petroleum 5:335-340. https://doi.org/10.1016/j.petlm.2018.12.007

Rizwanul Fattah IM, Ong HC, Mahlia TMI, Mofijur M, Silitonga AS, Rahman SMA, Ahmad A (2020) State of the art of catalysts for biodiesel production. Frontiers in Energy Research.

Ryckebosch E, Drouillon M, Vervaeren H (2011) Techniques for transformation of biogas to biomethane. Biomass Bioenerg 35:16331645. https://doi.org/10.1016/j.biombioe.2011.02.033
Sahota S, Shah G, Ghosh P, Kapoor R, Sengupta S, Singh P, Vijay V, Sahay A, Vijay VK, Thakur IS (2018) Review of trends in biogas upgradation technologies and future perspectives. Bioresour Technol Reports 1:79-88. https://doi.org/10.1016/j.biteb. 2018.01.002

Sarker S, Lamb JJ, Hjelme DR, Lien KM (2018) Overview of recent progress towards in-situ biogas upgradation techniques. Fuel 226:686-697. https://doi.org/10.1016/j.fuel.2018.04.021

Savvas S, Donnelly J, Patterson T, Chong ZS, Esteves SR (2017) Biological methanation of $\mathrm{CO} 2$ in a novel biofilm plug-flow reactor: a high rate and low parasitic energy process. Appl Energy 202:238-247. https://doi.org/10.1016/j.apenergy.2017.05.134

Selatile MK, Ray SS, Ojijo V, Sadiku R (2018) Recent developments in polymeric electrospun nanofibrous membranes for seawater desalination. RSC Adv 8:37915-37938. https://doi.org/10.1039/ C8RA07489E

Serejo ML, Posadas E, Boncz MA, Blanco S, García-Encina P, Muñoz $R$ (2015) Influence of biogas flow rate on biomass composition during the optimization of biogas upgrading in microalgal-bacterial processes. Environ Sci Technol 49:3228-3236. https://doi. org/10.1021/es5056116

Sheets JP, Shah A (2018) Techno-economic comparison of biogas cleaning for grid injection, compressed natural gas, and biogasto-methanol conversion technologies. Biofuels, Bioprod Biorefin 12:412-425. https://doi.org/10.1002/bbb.1848

Siddiki SYA, Uddin M, Mofijur M, Fattah I, Ong HC, Lam SS, Kumar PS, Ahmed SF (2021) Theoretical calculation of biogas production and greenhouse gas emission reduction potential of livestock, poultry and slaughterhouse waste in Bangladesh. J Environ Chem Eng 9:105204. https://doi.org/10.1016/j.jece.2021.105204

Silitonga AS, Masjuki HH, Ong HC, Sebayang AH, Dharma S, Kusumo F, Siswantoro J, Milano J, Daud K, Mahlia TMI, Chen WH, Sugiyanto B (2018) Evaluation of the engine performance and exhaust emissions of biodiesel-bioethanol-diesel blends using kernel-based extreme learning machine. Energy 159:10751087. https://doi.org/10.1016/j.energy.2018.06.202

Silva DA, Al-Gousous J, Davies NM, Chacra NB, Webster GK, Lipka E, Amidon G, Löbenberg R (2019) Simulated, biorelevant, clinically relevant or physiologically relevant dissolution media: the hidden role of bicarbonate buffer. Eur J Pharm Biopharm 142:819. https://doi.org/10.1016/j.ejpb.2019.06.006

Singhal S, Agarwal S, Arora S, Sharma P, Singhal N (2017) Upgrading techniques for transformation of biogas to bio-CNG: a review. Int J Energy Res 41:1657-1669. https://doi.org/10.1002/er.3719

Srivastava RK, Shetti NP, Reddy KR, Aminabhavi TM (2020) Biofuels, biodiesel and biohydrogen production using bioprocesses. Rev Environ Chem Lett 18:1049-1072. https://doi.org/10.1007/ s10311-020-00999-7

Stolecka K, Rusin A (2021) Potential hazards posed by biogas plants. Renew Sustain Energy Rev 135:110225. https://doi.org/10. 1016/j.rser.2020.110225

Struk M, Kushkevych I, Vítězová M (2020) Biogas upgrading methods: recent advancements and emerging technologies. Rev Environ Sci Bio/technol 19:651-671. https://doi.org/10.1007/ s11157-020-09539-9

Sun Q, Li H, Yan J, Liu L, Yu Z, Yu X (2015) Selection of appropriate biogas upgrading technology-a review of biogas cleaning, upgrading and utilisation. Renew Sustain Energy Rev 51:521532. https://doi.org/10.1016/j.rser.2015.06.029

Thrän D, Billig E, Persson T, Svensson M, Daniel-Gromke J, Ponitka J, Seiffert M (2014) Biomethane: status and factors affecting market development and trade: a joint study. IEA Bioenergy.

Toledo-Cervantes A, Estrada JM, Lebrero R, Muñoz R (2017a) A comparative analysis of biogas upgrading technologies: photosynthetic versus physical/chemical processes. Algal Res 25:237243. https://doi.org/10.1016/j.algal.2017.05.006 
Toledo-Cervantes A, Madrid-Chirinos C, Cantera S, Lebrero R, Muñoz $\mathrm{R}$ (2017b) Influence of the gas-liquid flow configuration in the absorption column on photosynthetic biogas upgrading in algalbacterial photobioreactors. Biores Technol 225:336-342. https:// doi.org/10.1016/j.biortech.2016.11.087

Towler G, Sinnott R (2012) Chemical engineering design: principles, practice and economics of plant and process design. Elsevier. https://doi.org/10.1016/C2009-0-61216-2

Tredici MR (2010) Photobiology of microalgae mass cultures: understanding the tools for the next green revolution. Biofuels 1:143162. https://doi.org/10.4155/bfs.09.10

Ullah Khan I, Hafiz Dzarfan Othman M, Hashim H, Matsuura T, Ismail AF, Rezaei-DashtArzhandi M, Wan Azelee I (2017) Biogas as a renewable energy fuel-A review of biogas upgrading, utilisation and storage. Energy Convers Manage 150:277-294. https://doi. org/10.1016/j.enconman.2017.08.035

Vega F, Baena-Moreno F, Fernández LMG, Portillo E, Navarrete B, Zhang Z (2020) Current status of CO2 chemical absorption research applied to CCS: towards full deployment at industrial scale. Appl Energy 260:114313. https://doi.org/10.1016/j.apene rgy.2019.114313

Vilardi G, Bassano C, Deiana P, Verdone N (2020) Exergy and energy analysis of biogas upgrading by pressure swing adsorption: dynamic analysis of the process. Energy Convers Manage 226:113482. https://doi.org/10.1016/j.enconman.2020.113482

Vo TT, Wall DM, Ring D, Rajendran K, Murphy JD (2018) Technoeconomic analysis of biogas upgrading via amine scrubber, carbon capture and ex-situ methanation. Appl Energy 212:11911202. https://doi.org/10.1016/j.apenergy.2017.12.099

Vrbová V, Ciahotný K (2017) Upgrading biogas to biomethane using membrane separation. Energy Fuels 31:9393-9401. https://doi. org/10.1021/acs.energyfuels.7b00120

Wahono SK, Stalin J, Addai-Mensah J, Skinner W, Vinu A, Vasilev K (2020) Physico-chemical modification of natural mordeniteclinoptilolite zeolites and their enhanced $\mathrm{CO} 2$ adsorption capacity. Microporous Mesoporous Mater 294:109871. https://doi.org/ 10.1016/j.micromeso.2019.109871

Wang Z, Dinh D, Scott WC, Williams ES, Ciarlo M, DeLeo P, Brooks BW (2019) Critical review and probabilistic health hazard assessment of cleaning product ingredients in all-purpose cleaners, dish care products, and laundry care products. Environ Int 125:399417. https://doi.org/10.1016/j.envint.2019.01.079

Wang H, Ma C, Yang Z, Lu X, Ji X (2020) Improving high-pressure water scrubbing through process integration and solvent selection for biogas upgrading. Appl Energy 276:115462. https://doi.org/ 10.1016/j.biortech.2013.07.049

Wang W, Xie L, Luo G, Zhou Q, Angelidaki I (2013) Performance and microbial community analysis of the anaerobic reactor with coke oven gas biomethanation and in situ biogas upgrading. Bioresour Technol 146:234-239. https://doi.org/10.1016/j.biortech.2013. 07.049

Wylock CE, Budzianowski WM (2017) Performance evaluation of biogas upgrading by pressurized water scrubbing via modelling and simulation. Chem Eng Sci 170:639-652. https://doi.org/10. 1016/j.ces.2017.01.012

Xu X, Gu X, Wang Z, Shatner W, Wang Z (2019) Progress, challenges and solutions of research on photosynthetic carbon sequestration efficiency of microalgae. Renew Sustain Energy Rev 110:65-82. https://doi.org/10.1016/j.rser.2019.04.050

Yentekakis IV, Goula G (2017) Biogas management: advanced utilization for production of renewable energy and added-value chemicals. Front Environ Sci 5:7. https://doi.org/10.3389/fenvs. 2017.00007
Yong WF, Zhang H (2020) Recent advances in polymer blend membranes for gas separation and pervaporation. Prog Mater Sci 116:100713. https://doi.org/10.1016/j.pmatsci.2020.100713

Yousef AM, Eldrainy YA, El-Maghlany WM, Attia A (2016) Upgrading biogas by a low-temperature $\mathrm{CO}_{2}$ removal technique. Alex Eng J 55:1143-1150. https://doi.org/10.1016/j.aej.2016.03.026

Yu Z, Wang H, Kong X, Huang W, Tsao Y, Mackanic DG, Wang K, Wang X, Huang W, Choudhury S (2020) Molecular design for electrolyte solvents enabling energy-dense and long-cycling lithium metal batteries. Nat Energy 5:526-533. https://doi.org/ 10.1038/s41560-020-0634-5

Zabed HM, Akter S, Yun J, Zhang G, Zhang Y, Qi X (2020) Biogas from microalgae: technologies, challenges and opportunities. Renew Sustain Energy Rev 117:109503. https://doi.org/10. 1016/j.rser.2019.109503

Zabranska J, Pokorna D (2018) Bioconversion of carbon dioxide to methane using hydrogen and hydrogenotrophic methanogens. Biotechnol Adv 36:707-720. https://doi.org/10.1016/j.biote chadv.2017.12.003

Zamri MFMA, Hasmady S, Akhiar A, Ideris F, Shamsuddin AH, Mofijur M, Fattah IMR, Mahlia TMI (2021) A comprehensive review on anaerobic digestion of organic fraction of municipal solid waste. Renew Sustain Energy Rev 137:110637. https://doi.org/ 10.1016/j.rser.2020.110637

Zhang Y, Kawasaki Y, Oshita K, Takaoka M, Minami D, Inoue G, Tanaka T (2021) Economic assessment of biogas purification systems for removal of both $\mathrm{H} 2 \mathrm{~S}$ and siloxane from biogas. Renew Energy 168:119-130. https://doi.org/10.1016/j.renene.2020.12.058

Zhang X, Liu H, Liang Z, Idem R, Tontiwachwuthikul P, Al-Marri MJ, Benamor A (2018) Reducing energy consumption of CO2 desorption in $\mathrm{CO} 2$-loaded aqueous amine solution using $\mathrm{A} 12 \mathrm{O} 3$ / HZSM-5 bifunctional catalysts. Appl Energy 229:562-576. https://doi.org/10.1016/j.apenergy.2018.07.035

Zhang Y, Oshita K, Kusakabe T, Takaoka M, Kawasaki Y, Minami D, Tanaka T (2020c) Simultaneous removal of siloxanes and H2S from biogas using an aerobic biotrickling filter. J Hazard Mater 391:122187. https://doi.org/10.1016/j.jhazmat.2020.122187

Zhang N, Pan Z, Zhang Z, Zhang W, Zhang L, Baena-Moreno FM, Lichtfouse E (2020a) CO 2 capture from coalbed methane using membranes: a review. Environ Chem Lett 18:79-96. https://doi. org/10.1007/s10311-019-00919-4

Zhang S, Shen Y, Wang L, Chen J, Lu Y (2019) Phase change solvents for post-combustion $\mathrm{CO} 2$ capture: principle, advances, and challenges. Appl Energy 239:876-897. https://doi.org/10.1016/j. apenergy.2019.01.242

Zhang X, Xiong W, Peng L, Wu Y, Hu X (2020b) Highly selective absorption separation of $\mathrm{H} 2 \mathrm{~S}$ and $\mathrm{CO} 2$ from $\mathrm{CH} 4$ by novel azolebased protic ionic liquids. AIChE J 66:e16936. https://doi.org/ 10.1002/aic.16936

Zhao X, Zhou H, Sikarwar VS, Zhao M, Park A-HA, Fennell PS, Shen L, Fan L-S (2017) Biomass-based chemical looping technologies: the good, the bad and the future. Energy Environ Sci 10:1885-1910. https://doi.org/10.1039/C6EE03718F

Zheng L, Cheng S, Han Y, Wang M, Xiang Y, Guo J, Cai D, Mang H-P, Dong T, Li Z (2020) Bio-natural gas industry in China: current status and development. Renew Sustain Energy Rev 128:109925. https://doi.org/10.1016/j.rser.2020.109925

Zhuang R, Wang X, Guo M, Zhao Y, El-Farra NH, Palazoglu A (2020) Waste-to-hydrogen: recycling $\mathrm{HCl}$ to produce $\mathrm{H} 2$ and $\mathrm{Cl} 2$. Appl Energy 259:114184. https://doi.org/10.1016/j.apenergy.2019.114184 